\title{
Bioprospecting of microbial strains for biofuel production: metabolic engineering, applications, and challenges
}

Mobolaji Felicia Adegboye1, Omena Bernard Ojuederie ${ }^{1,2}$, Paola M. Talia ${ }^{3,4}$ and Olubukola Oluranti Babalola ${ }^{1 *}$ (D)

\begin{abstract}
The issues of global warming, coupled with fossil fuel depletion, have undoubtedly led to renewed interest in other sources of commercial fuels. The search for renewable fuels has motivated research into the biological degradation of lignocellulosic biomass feedstock to produce biofuels such as bioethanol, biodiesel, and biohydrogen. The model strain for biofuel production needs the capability to utilize a high amount of substrate, transportation of sugar through fast and deregulated pathways, ability to tolerate inhibitory compounds and end products, and increased metabolic fluxes to produce an improved fermentation product. Engineering microbes might be a great approach to produce biofuel from lignocellulosic biomass by exploiting metabolic pathways economically. Metabolic engineering is an advanced technology for the construction of highly effective microbial cell factories and a key component for the next-generation bioeconomy. It has been extensively used to redirect the biosynthetic pathway to produce desired products in several native or engineered hosts. A wide range of novel compounds has been manufactured through engineering metabolic pathways or endogenous metabolism optimizations by metabolic engineers. This review is focused on the potential utilization of engineered strains to produce biofuel and gives prospects for improvement in metabolic engineering for new strain development using advanced technologies.
\end{abstract}

Keywords: CRISPER/Cas9, Lignocellulose, Fermentation, Metabolic pathways, Microbial cell factories, Model strains

\section{Background}

The continuous increase in global consumption of energy presently anticipated a rise in energy demand that will not be met in the short term. The depletion of fossil fuel reservoirs and climate change issues are strong indicators of the need for renewable and sustainable fuel alternatives [1]. Production of renewable fuels, biodegradable and environmentally friendly, is seen as a significant potential substitute for fossil fuel [2]. Lignocellulosic biomass serves as a reliable feedstock for renewable energy since it is admittedly not in competition with

\footnotetext{
*Correspondence: olubukola.babalola@nwu.ac.za

${ }^{1}$ Food Security and Safety Niche Area, Faculty of Natural and Agricultural Sciences, North-West University, Mmabatho, Private Bag X2046, 2735, South Africa

Full list of author information is available at the end of the article
}

food. Lignocellulose biomass is cultivated primarily for biofuel production such as poplar, sunflower, and jatropha, which are used as feedstocks for biofuel production. They are found abundantly in nature and are available globally, making them an attractive source of biomass for biofuel production. They also have significant advantages over first-generation biomass feedstocks since they are not used as food sources $[3,4]$. Biofuel produced from lignocellulosic feedstock has been proven to be environmentally friendly, helps reduce dependence on fossil fuel [5], serves as an alternative for declining petroleum reservoirs, and also provides an economic improvement, especially to rural communities [6].

Microbes from various habitats naturally produce a broad array of bioactive compounds that are used as fuels, drugs, and other important chemicals [7-9]. They

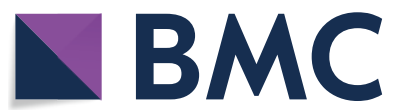

(c) The Author(s) 2021. This article is licensed under a Creative Commons Attribution 4.0 International License, which permits use, sharing, adaptation, distribution and reproduction in any medium or format, as long as you give appropriate credit to the original author(s) and the source, provide a link to the Creative Commons licence, and indicate if changes were made. The images or other third party material in this article are included in the article's Creative Commons licence, unless indicated otherwise in a credit line to the material. If material is not included in the article's Creative Commons licence and your intended use is not permitted by statutory regulation or exceeds the permitted use, you will need to obtain permission directly from the copyright holder. To view a copy of this licence, visit http://creativeco mmons.org/licenses/by/4.0/. The Creative Commons Public Domain Dedication waiver (http://creativecommons.org/publicdomain/ zero/1.0/) applies to the data made available in this article, unless otherwise stated in a credit line to the data. 
have excelled at producing biofuel through the biosynthesis of enzymes that act on diverse feedstocks for many years under different processes [10]. Most strategies for converting lignocellulosic biomass to biofuels require the depolymerization of polysaccharides catalyzed by the action of specific enzymes. However, one of the key impediments for the development of an economically feasible lignocellulose-based biofuel industry is the cost of enzymes [11, 12]. Nonetheless, intensive studies are ongoing globally, towards increasing biofuel production whilst reducing the cost of production for sustainable industries [13-16]. Microbial strain development and improvement through genetic engineering and optimization of fermentation parameters have augmented the production of biofuel. Although one of the main drawbacks is the method for optimizing various processes for maximal yield, the incorporation of process engineering, fermentation technology, enzyme engineering, and metabolic engineering has helped the industry tremendously.

The advent of metabolic engineering and the increase in the number of whole-genome sequenced organisms has contributed to improvement in the manipulation of microbial metabolic pathways and the production of numerous essential chemicals for the production of biofuel $[17,18]$. The manipulation and evolution of different pathway enzymes also serve as a platform to increase the number and types of bioactive compounds that can be biosynthesized by microorganisms [19]. The biosynthesis of advanced biofuels such as alkanes, alkenes, and aromatics by microbes will involve an extensive manipulation of their metabolism. This review discusses the importance of model strains by metabolic engineering as a powerful tool to enhance biofuel production from lignocellulosic biomass and the challenges encompassed therein.

\section{Structure of lignocellulosic biomass feedstock}

Lignocellulose constitutes the world's largest biofuel renewable resource. They are the major source of underutilized feedstock, and their abundance negatively affects land use. Biomass feedstock from plants is naturally recalcitrant because of the complex polymer composition [20]. Lignocellulose, a complex carbohydrate polymer on a dry matter basis, comprises about $40-50 \%$ cellulose $\left[\left(\mathrm{C}_{6} \mathrm{H}_{10} \mathrm{O}_{5}\right) \mathrm{n}\right], 20-40 \%$ hemicellulose $\left[\left(\mathrm{C}_{5} \mathrm{H}_{8} \mathrm{O}_{4}\right)\right.$ $\mathrm{m}], 18-25 \%$ lignin $\left[\left(\mathrm{C}_{9} \mathrm{H}_{10} \mathrm{O}_{3}\left(\mathrm{OCH}_{3}\right) 0.9-1.7\right) \mathrm{x}\right]$ and other extractable components [21]. The relative abundances of these three fractions are significant factors to be considered for probable energy production. Each component has a definite function in lignocellulose. Strength and flexibility are provided by cellulose, while hemicellulose acts as a link between lignin and cellulose fibers (Fig. 1). Apart from keeping cellulose and hemicellulose fibers glued together, lignin also gives structural support.

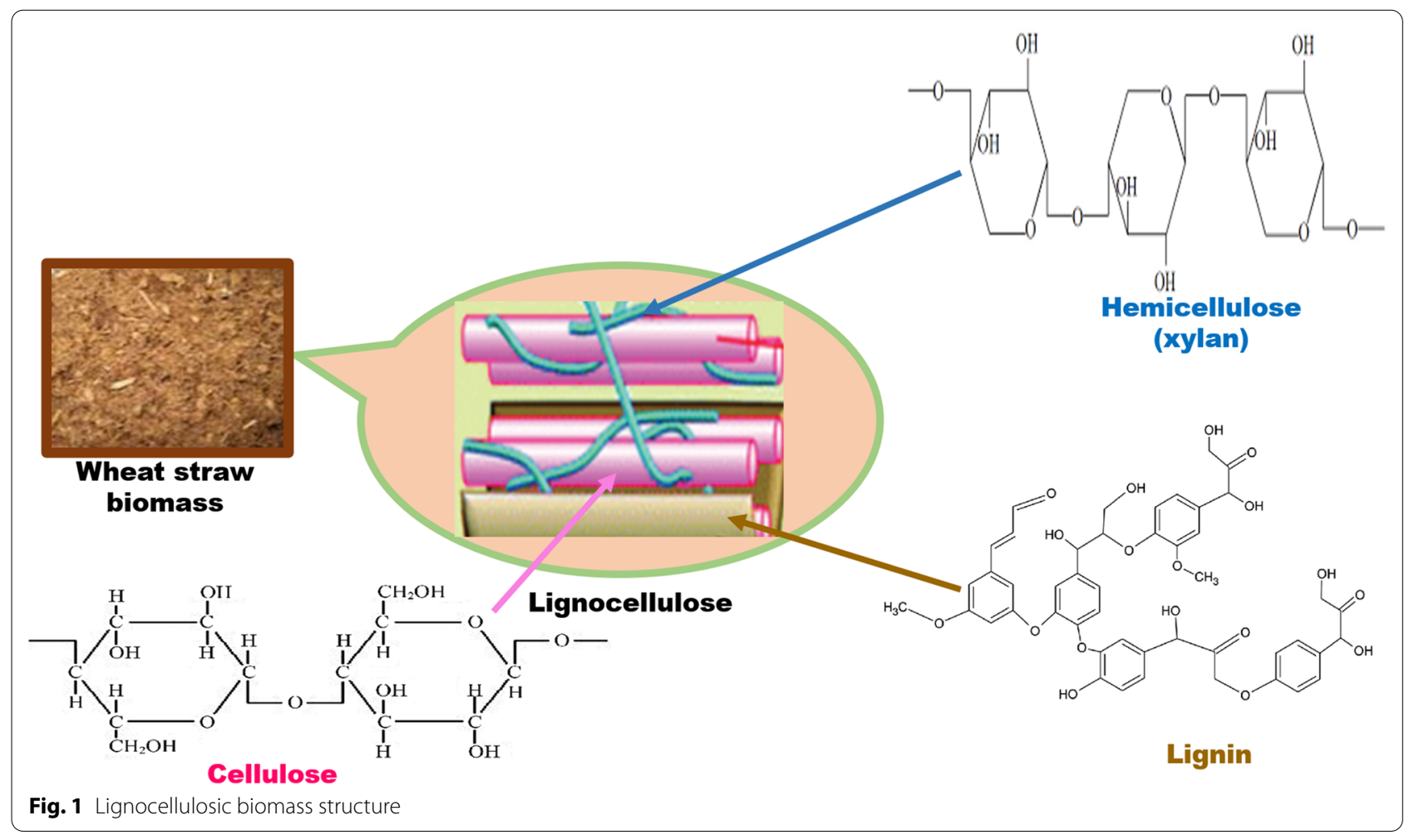


Cellulose is an unbranched crystalline biopolymer made up of several repeating glucose units linked by $\beta-1,4$ glycosidic bonds [22]. Cellulose has a molecular weight of $1621,406 \mathrm{~g} / \mathrm{mol}$. It is biosynthesized and found in the cell wall of plants joined by hydrogen bonding and van der Waals forces. Cellulose is insoluble in most solvents due to the strong hydrogen bonds and its fibrous nature [23]. Cellulose occurs in both crystalline and amorphous forms. In its crystalline form, the fibers are packed very tightly and practically inaccessible to enzymatic degradation.

Hemicellulose is a heteropolymer of several kinds of sugars (xylose, arabinose, rhamnose, galactose, and mannose). It may contain uronic acids, which are sugar acids known as D-glucuronic, D-galacturonic, and methylgalacturonic acids [24]. It is a short, amorphous, and highly branched polymer and its backbone chain comprises mainly xylan $\beta(1 \rightarrow 4)$ linkages [25]. Xylan is the predominant component in hemicellulose, but its composition varies from one feedstock to another. The molecular weight of hemicellulosic biomass is about $30,000 \mathrm{~g} / \mathrm{mol}$ or less.

Lignin is a three-dimensional aromatic polymer of $p$-hydroxyphenylpropanoid units coupled together by $\mathrm{C}-\mathrm{C}$ and $\mathrm{C}-\mathrm{O}-\mathrm{C}$ links $[25,26]$. It is hydrophobic and is firmly bound to the two other carbohydrate polymers. Lignin is made up of three phenolic monomers of phenyl propionic alcohol namely, p-coumaryl, coniferyl, and sinapyl [24]. It contains methoxyl, phenolic, hydroxyl, and terminal aldehyde groups in the side chain and partially soluble in most organic solvents. The average molecular weight of lignin is about 20,000 [23]. Because of the diversity of the lignocellulose component and their recalcitrance, its complete hydrolysis into monomers is catalyzed by several enzymes. The complete utilization of these components would play an important part in the economic effectiveness of the lignocellulose in biofuel processes.

\section{Lignocelluloytic enzymes involved in polysaccharide biomass hydrolysis}

Lignocellulosic biomass is the predominant and costeffective renewable natural resource globally employed for biofuel production as a result of its high cellulose content [27]. Nonetheless, due to the recalcitrance nature of lignocellulose, its depolymerization is hindered. Lignocellulases such as cellulases, hemicellulases, pectinases, as well as lignases and polysaccharide oxygenases, are required to completely breakdown lignocellulose. These hydrolytic enzymes stimulate plant cell wall extension indirectly by decreasing the size and viscosity of matrix polymers, potentially augmenting the action of wall loosening agents $[28,29]$. The cell wall of plants comprises cellulose and hemicellulose, which, when hydrolyzed, gives rise to fermentable sugars such as glucose, galactose, etc. which serves as a carbon source for the proliferation of microbes involved in biofuel production. Based on their structure and function, cellulases can be categorized into three types; (i) endoglucanases, (ii) exoglucanases, also known as cellobiohydrolases, and (iii) $\beta$-glucosidases, also called cellobiases [27]. These enzymes work in unison to hydrolyze cellulose in the cell wall of plants. Endoglucanases act by randomly attacking the internal sites of the amorphous part of cellulose, thereby paving the way for cellobiohydrolase action on the crystalline region of cellulose hydrolyzing it to cellobiose [30-32]. The synergistic action of endoglucanase and cellobiohydrolase produces cellobiose, which is then cleaved by $\beta$-glucosidases to glucose molecules. Microbes then utilize the energy stored in glucose converting it to hydrocarbon fuel through transforming the sunlight energy to chemical energy [33,34]. The activities of the different cellulases are governed by their functional properties, which have been extensively reviewed by Obeng et al. [27]. Table 1 describes the various functional properties of the three groups of cellulases.

Since hemicellulose is a heteropolymer consisting of a complex polysaccharide matrix composed of monomeric sugars and sugar acids linked together by $\beta$ 1,4and $\beta 1,3$-glycosidic bonds, a combination of exo and endo-enzymes are required to completely cleave the internal bonds and set the monomeric sugars free [35, 36]. Hemicellulose is degraded by enzymes that act on xylan, degrading it to lower molecular weight oligosaccharides. The first of these enzymes is endo $\beta-1,4$ xylanase (E.C.3.2.1.8), which cleaves $\beta-1,4$ xylosidic bonds in xylan to xylo-oligosaccharides which is then converted to xylose, The other enzyme xylan $\beta-1,4$ xylosidase otherwise known as xylan $\beta-1,4$ xylosidase (E.C.3.2.1.37), cleaves xylobiose and smaller xylo-oligosaccharides to xylose (Fig. 2). These hemicellulose degrading enzymes are produced by bacterial and fungal species. For example, endo $\beta-1,4$ xylanase of the CAZy family (GH5, GH7, GH8, GH10, GH11, and GH43) are synthesized by fungi such as the Trichoderma longibrachiatum, Aspergillus niger, and Ustilago maydis [36-38].

Most of the xylanases fall under the GH10 and GH11 families, which differ in their substrate specificity, with GH10 having a wider specificity than GH11 endoxylanase family [42-44]. Other hemicellulolytic enzymes that work in synergism with the xylanase include $\beta$-mannanases and arabinofuranosidases, which play key roles in the cleavage of hemicelluloses composed of mannan or arabinofuranosyl facilitating the catalytic action of xylanase on xylan [45]. Bhardwaj et al. [46] recently gave an extensive review of microbial xylanases, highlighting 
Table 1 Functional and structural properties of cellulases

\begin{tabular}{|c|c|c|c|c|}
\hline Type of cellulase & EC Number & Functions & Structural properties & References \\
\hline Endoglucanases & EC 3.2.1.4 & $\begin{array}{l}\text { Breaks internal linkages of cellulose } \\
\text { molecules, producing cellobiose and } \\
\text { possesses rapid dissociation capacity }\end{array}$ & $\begin{array}{l}\text { They possess short loops that stick along } \\
\text { cellulose chains to yield long-chain } \\
\text { oligomers }\end{array}$ & {$[27,39]$} \\
\hline Exoglucanases or Cellobiohydrolases, & EC 3.2.1.74 & $\begin{array}{l}\text { Cleave the same glycosidic bond from } \\
\text { terminal ends of cellulose molecules, } \\
\text { producing cellobiose }\end{array}$ & $\begin{array}{l}\text { They possess long loops and attracted } \\
\text { to crystalline sites along cellulose } \\
\text { microfibril chains and produce mainly } \\
\text { Cellodextrin } \\
\text { It exists in two forms based on the part } \\
\text { of the oligosaccharide chain that is } \\
\text { attacked. The reducing end and non- } \\
\text { reducing end of cellobiohydrolase }\end{array}$ & {$[27,39,40]$} \\
\hline$\beta$-glucosidases or cellobiases & EC 3.2.1.21 & $\begin{array}{l}\text { Cleaves cellobiose into two glucose } \\
\text { molecules }\end{array}$ & $\begin{array}{l}\text { It has a solid structure with the function- } \\
\text { ing site within a pocket which permits } \\
\text { the entry of disaccharides. It has } 2 \\
\text { forms which catalyze hydrolysis either } \\
\text { from the reducing chain ends or the } \\
\text { non-reducing chain ends }\end{array}$ & {$[22,27,41]$} \\
\hline
\end{tabular}

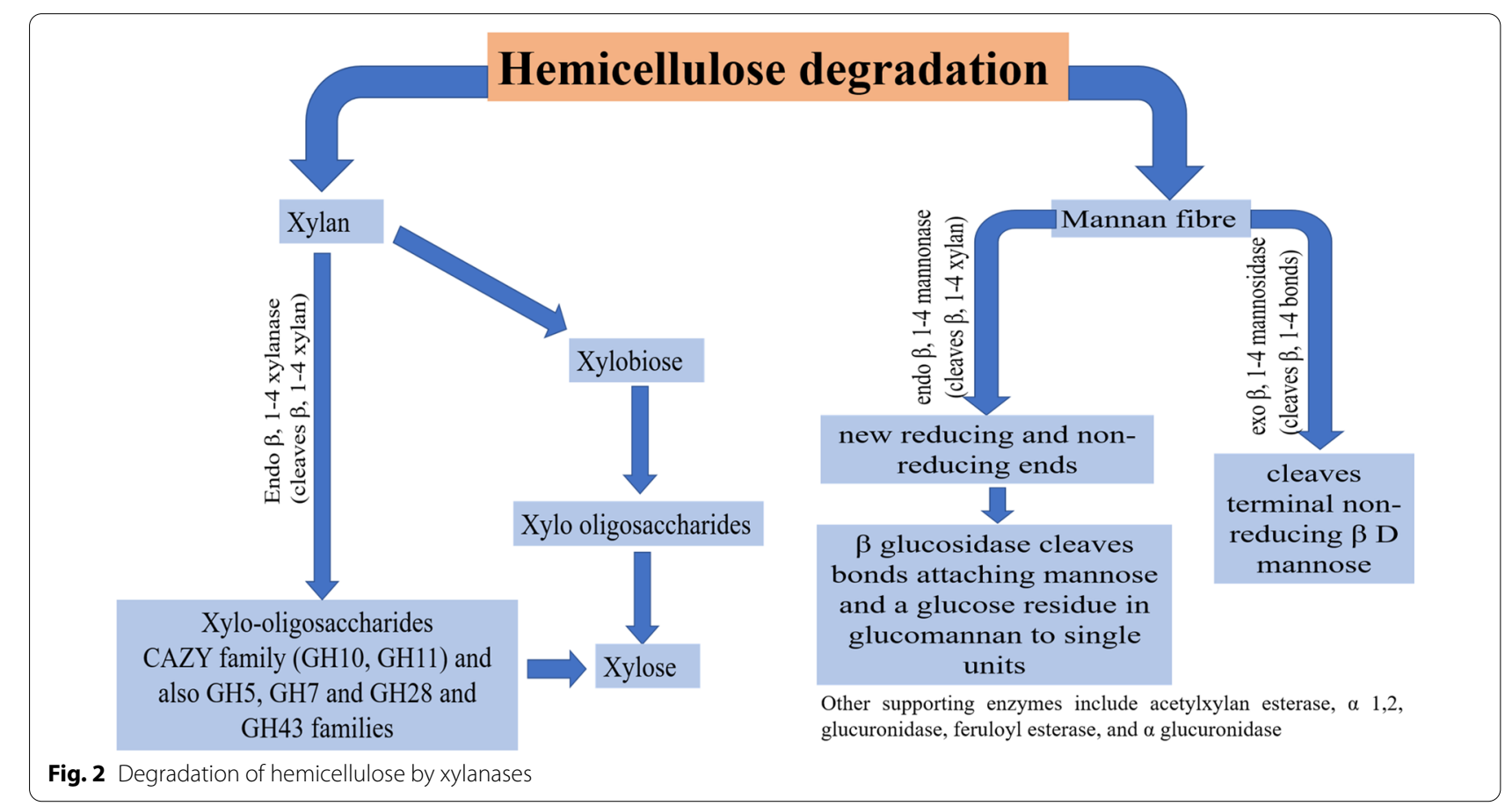

the different families as well as its synthesis and applications in an emerging bioeconomy.

Apart from cellulose and hemicellulose, lignocellulosic biomass also contains little proportion of polysaccharides called pectin, which accounts for about $5 \%$ of total dry weight and is often found as a major component of agricultural wastes [47]. Pectin is composed of $\alpha-1,4-\mathrm{D}-$ galacturonic acid linkages. These linkages are hydrolyzed by three different types of pectinases: hydrolases, lyases, and esterase based on their mode of action [48].
Hydrolases come in two forms depending on if the cleavage occurs within the molecule or at the terminal end.

Endopolygalacturonase (EC 3.2.1.15) hydrolyzes homogalacturonan in pectic acid and oligomers by releasing digalacturonic and galacturonic acid units from their reducing ends, while exopolygalacturonase (EC 3.2.1.67) acts on the reducing end of galacturonyloligomers produced by endopolygalacturonase, cleaving the $\alpha 1,4$-glycosidic bonds and subsequently releasing galacturonic acid from the non-reducing end [47, 49]. 
Esterase (EC 3.1.1.11) on the other hand, catalyzes the degradation of the methyl ester bonds in pectin by a deesterification process, resulting in the production of pectic acid [48]. Hence, it is also called pectin methylesterase [50]. Lastly, lyase catalyzes the breakdown of pectin by an elimination reaction, which leads to the formation of unsaturated galacturonates and methyl galacturonates [48].

Lytic polysaccharide monooxygenases (LPMOs) play essential roles in the bioconversion of recalcitrant polysaccharides such as chitin and cellulose [51-53], which is required for biofuel production. They belong to a group of copper-dependent oxygenase that split polysaccharides into monomeric units [54]. LPMOs were first identified in fungi as far back as 1990 during a bioprospecting study, as a cellulose-degrading hydrolase [55-57]. It was initially placed in the glycoside hydrolase family GH61 and CBM33 in the CAZy database of carbohydrate-active enzymes [58], but the name later changed to polysaccharide monooxygenases (PMOs) in 2011 and subsequently LPMO [57, 59-63]. Thermoascus aurantiacus, a cellulase in the GH61 family, was first confirmed as having the ability to hydrolyze lignocellulosic biomass leading to the re-classification from GH61 to AA9 family, and CBM33 to AA10 family of LPMOs [54, 61, 64]. Some enzymes have recently been found to degrade hemicellulose substrates in addition to cello-oligosaccharide substrates [54, 65]. In the case of bacterial enzymes in the AA10 family, they act on cellulose and chitin unlike the AA9 family, which acts on cellulose and hemicellulose. LPMOs of the AA9 family were identified in several strains of fungi, including T. terrestris, Neurospora crassa, Podospora anserine, Aspergillus nidulans, Myceliophthora thermophila, and Sporotrichum pulyverolentum [54, 64, 66-68].

The catalytic action of LPMO from Aspergillus nidulans on the oxidative degradation of different types of polysaccharides was studied by Jagadeeswaran et al. [68]. An AA9 LPMO in A. nidulans the AN3046 was found to be very active in the degradation of cellulose and hemicellulose xyloglucan, which also had a synergistic effect with some sorghum stover degrading hydrolases as it resulted in approximately 1.25 -fold increase in glucose yield compared to sole treatment with endoglucanase EglA [68]. In another study, an LPMO from Aspergillus niger AnLPMO15g, enhanced the catalytic ability of cellulase in the degradation of Avicel ${ }^{\circledR}$ and straw, which resulted in an increase in the reducing sugar yield by 1.93 and 2.31 times more than that obtained from using only cellulase [54]. The AnLPMO15g enzyme had more activity on Avicel ${ }^{\circledR}$ than other substrates producing the highest yield compared to the other substrates, indicating a high activity of oxidative cleavage on $\beta-1,6$ glycosidic bonds [54]. Since the AnLPMO15g also yielded reducing sugars with xylan as a substrate, it has the potential to act not only on $\beta-1,6$ glycosidic bonds found in cellulose but also the $\beta-1,4$ xylosidic bonds in xylan. From the study of Du et al. [54], we can understand clearly that the synergistic effect of the LPMOs such as AnLPMO15g in increasing the yield of reducing sugars, is dependent on the type of substrate used. This is an important factor to be taken into consideration when selecting LPMOs for biofuel production. Extensive reviews on the mechanism of action of LPMOs in lignocellulosic biomass degradation have been recently published $[51,54,57,64]$.

\section{Fermentation of lignocellulosic biomass for biofuel production}

Bioconversion of lignocellulosic biomass feedstock to biofuel is gaining significant prominence globally. Bioconversion of lignocellulose to biofuels entails four main processes: (1) the pretreatment process, which can be physical, chemical, or both that involves depolymerizing the biomass partially, (2) the enzymatic process, which involves cleaving polysaccharides to simple sugars by the actions of glycan-depolymerizing enzymes, (3) the fermentation process which involves converting the sugars to bioethanol, and (4) lastly, the distillation process which involves separating the bioethanol from water and residual solids [69].

The pretreatment of lignocellulosic biomass and reduction in the cost of the hydrolysis step are major drawbacks to the improvement of biofuel production [70, 71]. The pretreatment process could either be by physical, chemical, or biological means. However, no single method is efficient. Thus, a combination of chemical and biological treatment is often used to obtain higher yields of reducing sugar. Compared to other pretreatment processes, biological pretreatment is found to be less expensive and operates under a mild condition. It requires the use of microorganisms to effectively degrade lignocellulosic feedstocks using different metabolic pathways, directed by the actions of hydrolyzing enzymes such as manganese peroxidases (EC 1.11.1.13), lignin peroxidases (EC 1.11.1.14), and laccases or white-rot fungi [72-75], with the removal of lignin.

Actinobacteria are an essential group of microorganisms known for their ability to degrade several substrates and synthesize products of economic value from the bioconversion of agricultural and urban wastes and the biotransformation of organic compounds [75]. Members of this group have been implicated in the biosynthesis of a wide array of useful enzymes such as xylanases [75-77], chitinases [75, 78], cellulases [75, 79], laccases [80, 81], and proteases $[75,82]$ required for the degradation of lignocelluloses, lignin, cellulose as well as plant residues [75, 
83-85]. Streptomyces spp. are recognized for their metabolic potentials, especially in the biosynthesis of antibiotics, and their capability to degrade a range of distinct compounds such as lignocellulose, keratin, pectin, xylan, cellulose, lignin, chitin as well as styrene $[5,75,86]$. Adegboye et al. [5] identified two new strains of Streptomyces (NWU339 and NWU49) isolated from maize rhizosphere soil, with the ability to utilize starch, xylan, and cellulose as substrates which could be used for biofuel production. The hydrolytic enzymes synthesized by Streptomyces fulvissimus CKS7 (amylase, cellulases (Carboxymethyl cellulase-CMCase and Avicelase), pectinase and xylanase [87], effectively hydrolyzed horsetail waste resulting in maximum yield of bioethanol from the fermentation process with Saccharomyces cerevisiae [87].

Apart from microbes, cellulolytic enzymes can be obtained from insects such as termites. In recent times, wood-eating termites have received much interest as a valuable source of cellulolytic enzymes, which are useful for biofuel production [88]. The Cohnella genus of bacteria is known for its high cellulolytic activities in different habitats, including the gut of termites. It was recently confirmed as been part of the cellulolytic microbiome associated with wood-eating termites and was identified in the intestinal tracts of three Neotropical termites Nasutitermes aquilinus, $N$. corniger, and Cortaritermes fulviceps [88]. These wood-eating termites are essential as they have an efficient lignocellulolytic digestion system that could be harnessed for the advancement of the current bioconversion mechanisms of lignocellulosic biomass for the production of useful bioproducts [89]. $\beta$-glucosidases have been reported mainly in the salivary glands and midgut of most Nasutitermes sp., and xylanases belonging to the GH10 and GH11 families isolated and recombinantly expressed from Nasutitermes sp. as well as Globitermes brachycerastes bacterial symbionts, respectively [90, 91]. Thus, termites should be considered as biological models for bioprocessing of cellulosic biomass [91]. Moreover, there is a need to utilize the advancement in omic technologies to identify key genes required for cellulolytic enzyme synthesis, which could be utilized for bioengineering of useful microbial strains for biofuel production.

Although biological pretreatment is regarded as the most effective delignification approach, factors such as particle size, moisture content, biomass type as well as the nature of the microorganism could hamper the pretreatment process [92]. Moreover, the biological pretreatment of lignocellulosic biomass is relatively slow and can take several days before it is fully hydrolyzed. The chemical pretreatment offers many potentials as it increases the porosity of the biomass as well as solid separation $[71,93]$. Nevertheless, due to the harmful effect of the chemicals used for pretreatment on the environment when been disposed of and the difficulties involved in recycling, the chemical pretreatment method is not frequently used alone [93-95]. The chemical pretreatment could be either acidic or alkaline. The flowchart for the production of bioethanol is presented (Fig. 3).

The use of acidic treatment is not recommended due to its toxicity to the microorganisms used in the fermentation process, and possibly corrosion to the fermentation vessels. Nevertheless, some researchers have reported appreciable yield of reducing sugars at concentrations $<4.0 \mathrm{wt} \%$ and temperatures of $120-210{ }^{\circ} \mathrm{C}$. Lu et al. [96] obtained a yield of $77 \%$ xylose and $8.4 \%$ glucose from the enzymatic degradation of corn stover following pretreatment with $\mathrm{H}_{2} \mathrm{SO}_{4}(2 \%)$ at $120{ }^{\circ} \mathrm{C}$ for just $43 \mathrm{~min}$, which was regarded as the optimum conditions for pretreatment [96, 97]. Whereas, Bhandari et al. [98] obtained a higher yield of xylose and glucose $(78.7 \%$ and $18.7 \%$ ) with $1.47 \mathrm{wt} \% \mathrm{H}_{2} \mathrm{SO}_{4}$ at $155{ }^{\circ} \mathrm{C}$ for $31 \mathrm{~min}$, and $78.1 \%$ xylose and $14.5 \%$ glucose yield at $182{ }^{\circ} \mathrm{C}$ for 36 min, respectively [98]. In a related study using olive tree biomass, pretreatment with $1 \% \mathrm{H}_{2} \mathrm{SO}_{4}$ at $180{ }^{\circ} \mathrm{C}$ gave a maximum overall yield of $75 \%$ of total sugar [99]. From the foregoing, it is evident that the yield obtained from enzymatic saccharification after pretreatment with the acid varied in terms of three factors, namely concentration of the acid, time of exposure, and temperature used with good yield obtained at a temperature of $120-182^{\circ} \mathrm{C}$. The use of sulfuric acid in the pretreatment step aids in the solubilization of hemicellulose into monomers which increases the digestibility of cellulose by hydrolytic enzymes $[92,100]$.

Alkaline pretreatment of lignocellulosic biomass is usually performed with $\mathrm{NaOH}$ at low temperature and pressure. It is most preferred to acidic pretreatment due to a reduction in the loss of carbohydrates during hydrolysis [92, 97, 101]. It is known to expel acetyl groups, thereby enhancing hydrolysis in the subsequent step and inhibit furfural formation [97], subsequently removing lignin and hemicellulose. Alkaline pretreatment is most suitable for agricultural wastes like wheat straw which enhances the digestibility of cellulose without degrading both hemicellulose and acid treatment [92]. The use of alkali pretreatment along with microbial hydrolysis of the pretreated biomass [32], has recently been shown to preserve polysaccharides while significantly removing lignin as was evident in wheat straw pretreated with $10 \% \mathrm{NaOH}$ which resulted in $72.67 \%$ yield of cellulose and removal of $69.5 \%$ lignin $[32,102]$. Moreover, total reducing sugars (83.68\%) were recovered after alkaline pretreatment of the wheat straw and microbial hydrolysis of cellulose and hemicellulose [32]. In many cases, the combination of biological and chemical pretreatments is more effective 


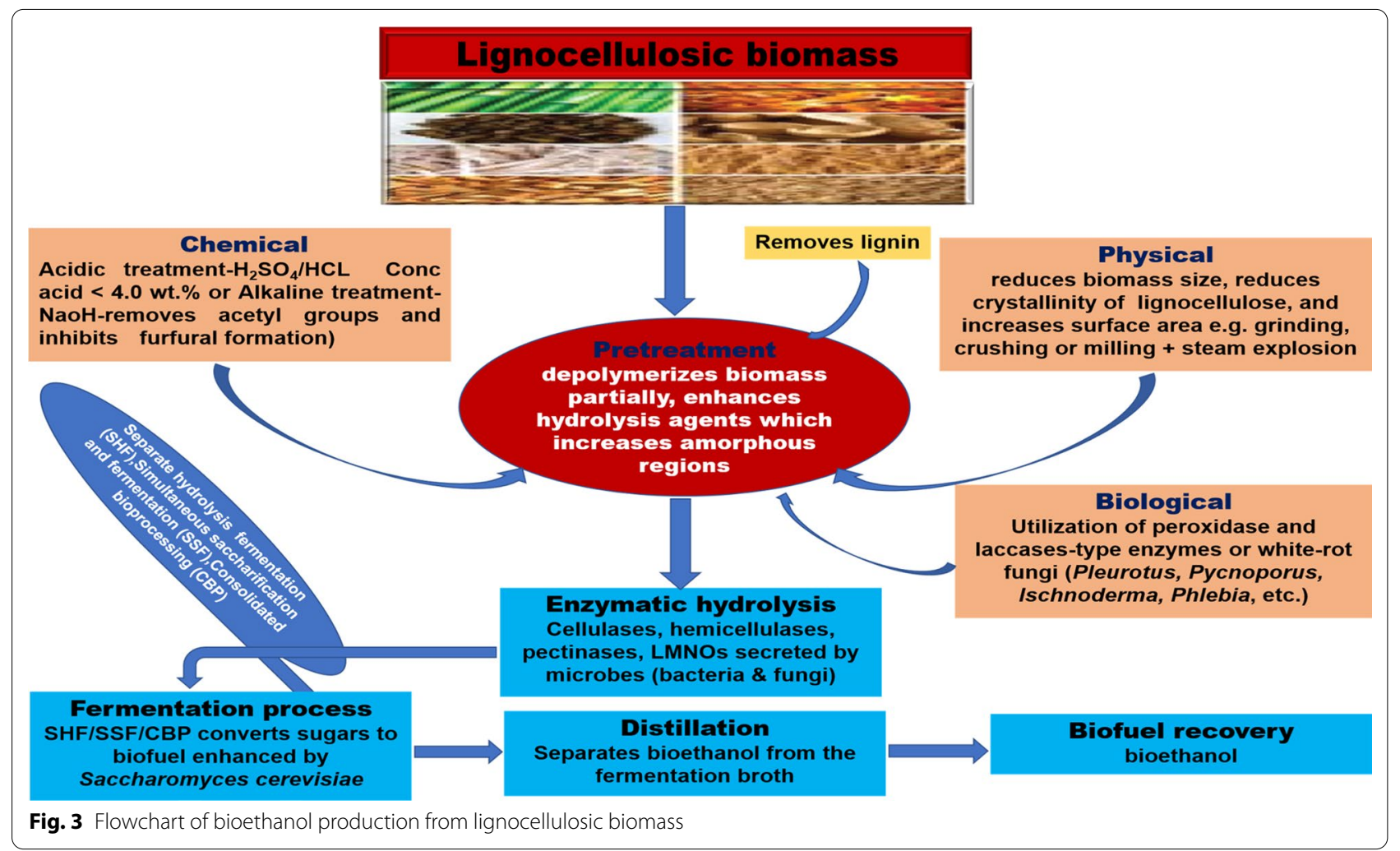

and requires less rigorous pretreatment conditions to efficiently hydrolyze the feedstock [103].

After the hydrolysis of the feedstock by the various enzymes [cellulase (endoglucanase, exoglucanase, and $\beta$ glucosidase), hemicellulase ( $\beta-1,4$ - xylanase, $\beta-1,4$ xylosidase), pectinases (hydrolase-endopolygalacturonase and exopolygalacturonase, Lyase-polygalacturonate Lyase and Polymethylgalacturonate Lyase, esterase and lytic polysaccharide monooxygenase)] as discussed above, the carbohydrate components (cellulose and hemicellulose) become fermentable. This attribute makes lignocellulosic biomass an attractive feedstock for biofuel production [104]. Through the process of fermentation, the hydrosylate obtained after removal of lignin in the pretreatment stage and hydrolysis is converted to biofuel. Yeast (Saccharomyces cerevisiae) is the preferred choice of microorganism for fermentation of sugars to bioethanol due to its ability to tolerate high ethanol concentrations and inhibitors produced during the fermentation process.

The fermentation process for ethanol production could occur in three ways; it could be run separately immediately after the hydrolysis step, which is regarded as separate hydrolysis and fermentation (SHF) [104], or the saccharification takes place simultaneously with fermentation, described as simultaneous saccharification and fermentation (SSF), or the production of cellulase, as well as the enzymatic reaction and fermentation, occur simultaneously in the same bioreactor, a process called consolidated bioprocessing (CBP). These fermentation methods are frequently used for bioethanol production, with increased yields obtained. However, each has its advantages and drawbacks.

The SHF provides optimum working conditions for hydrolysis and fermentation, which occurs in separate vessels at different temperatures and enables the recycling of the yeast used in fermentation [92]. Besides, it permits a continuous run of the fermentation process. Hydrolysis by cellulase occurs efficiently at a temperature range of $45-50{ }^{\circ} \mathrm{C}$, while fermentation by microbes occurs at temperatures of $30-37{ }^{\circ} \mathrm{C}$, resulting in ethanol production [92, 104-106]. Nevertheless, the end products (glucose and cellobiose) inhibit the activity of the cellulase enzyme and require more time to run the process $[92,97]$. $\beta$-glucosidase is inhibited by glucose, which elevates the level of cellobiose. Cellobiose subsequently inhibits cellulase, thereby reducing its efficiency [106, 107]. Furthermore, SHF is a two-step process that incurs additional cost, and it is time-consuming.

The SSF is the most preferred fermentation method for bioethanol production from lignocellulose as the processes of enzymatic hydrolysis and fermentation occurs 
within the same bioreactor, thereby reducing the cost of production, improving ethanol yield, as well as reducing the risks of contamination and enzyme inhibition by the end products of hydrolysis [92, 108]. This is made possible because before the inhibitory concentrations of the end products are reached, the glucose and cellobiose produced are simultaneously fermented to high-energydensity ethanol molecules [109]. Besides, different lignocellulosic substrates could be used under various pretreatment conditions that result in increased product yield within a short period [109]. SSF can be conducted using fermenting thermophilic bacterial strains and yeast cells such as Candida acidothermophilum and Kluyveromyces marxianus without compromising the optimal temperature of hydrolysis [109].

Mihajlovski et al. [87] obtained a high yield of bioethanol from the SSF of rye bran using crude enzymes produced by Streptomyces fulvissimus CKS7. A maximum reducing sugar yield of $2.55 \mathrm{mg} \mathrm{ml}^{-1}$ was obtained using horsetail as substrate after $72 \mathrm{~h}$ of hydrolysis followed by fermentation with waste brewer's yeast $S$. cerevisiae [87].

Despite the maximal yield of ethanol obtained through SSF of hexoses, there is a drawback in the fermentation of pentoses, which are omitted when only a hexose fermenting strain such as $S$. cerevisiae is used that makes it necessary to use a pentose-fermenting strain in a separate bioreactor after pretreatment, to complete the fermentation process [109]. Both SHF and SSF require the introduction of enzymes for hydrolysis.

In the case of CBP fermentation, a microbial consortia biocatalyst strategy is used by combining a cellulolytic strain capable of hydrolyzing hemicellulosic biomass to fermentable sugars, and a second strain that makes use of the cellulosic sugars for its growth and converts them to biofuel products during the fermentation process using its natural or engineered metabolic pathways [110]. Unlike the SHF and SSF, in the CBP, the three stages of enzyme synthesis, hydrolysis of lignocellulosic biomass, and fermentation occur concurrently in the same bioreactor. This reduces the cost of biofuel production as a result of less complicated feedstock processing, less energy expended, and higher conversion efficiencies [111]. However, before the CBP approach can be used, it requires microorganisms capable of producing a functional cellulase system while generating ethanol at high returns and concentrations [112]. In this regard, bacteria such as Clostridium thermocellum and fungi such as Neurospora crassa, Fusarium oxysporum, S. cerevisiae, and Paecilomyces sp. [104], come in handy for biofuel production (ethanol and butanol) using CBP approach [113-115].

After the fermentation process, the product obtained needs to undergo the purification process and distillation to separate the bioethanol from the fermentation broth to obtain the final pure bioethanol separating it from the fermentation broth. The amount of bioethanol produced from the fermentation process depends mainly on the number of sugars produced during pretreatment and for hydrolysis efficiency $[116,117]$.

The fermentation process for biofuel production is often expensive; hence, effort needs to be made to seek alternative means of making the process cost-effective. One such way is to reduce production cost through high solids loading as a result of reduced water uptake and downstream processing cost, and this ultimately helps to reduce environmental pollution [118]. Some difficulties arise because of the high loading of lignocellulose solids, for instance, inhibition of enzymes by end products. This can be overcome through the application of fed-batch processes $[108,119]$. The success of this kind of process can be measured by the total yield of bioethanol produced (volume of ethanol produced per dry weight of raw material) and the level of ethanol concentration in the fermentation batch [119].

\section{Strains for biofuel production}

The successful production of biofuel from lignocellulosic biomass depends mainly on finding and exploiting a suitable microorganism for the whole fermentation process [120]. The ideal strain for biofuel production should be able to completely utilize the pentose-rich and hexose containing sugars produced from lignocellulosic biomass feedstock, and that can survive the inhibitory compounds that are generated during the pretreatment step. Most of the organisms employed for fermentation are not able to utilize pentose sugars, and those that can ferment it are inhibited by end products and by-product formation $[121,122]$.

Saccharomyces cerevisiae and Zymomonas mobilis are the best-known alcohol fermenting microbes with the ability to ferment hexose sugars and sucrose into ethanol but are inhibited by end products [123, 124]. Moreover, pentose-fermenting organisms, Pichia stipitis, Candida shehatae, and Pachysolen tannophilus [125], are also inhibited by end products $[123,126]$. Even though filamentous fungi can withstand inhibitory compounds, their high generation time and lower yields and productivities make them unattractive candidates for biofuel production [125]. Thus, a microorganism that is inhibited by end products, and that also takes more time to hydrolyze the lignocellulosic biomass is not appropriate for industrial-scale production of biofuel [15].

The ideal strain can either be a natural cellulolytic biofuel-producing microbe or an engineered industrial strain conferred with the gene(s) to produce biofuel [120]. The ideal strain needs some attributes to use 
high amounts of substrates such as the ability to attain high cell mass growth and biofuel production rates in biomass-derived hydrolysates [127], the ability to use a wide range of pentose and hexose sugars withstand high temperatures and low $\mathrm{pH}[127,128]$, as well as to exhibit good tolerance to inhibitors and end products. This strain should also have high metabolic fluxes and biosynthesize single fermentation products for sugar transport through fast and deregulated pathways. It is easier and more economical to operate and control a bioreactor at extremely high temperatures. Operating high temperatures also advances reaction rates, viscosities of culture broth, and decreases the risk of contamination during production. Also, the ability to adapt to lower $\mathrm{pH}$ can help lessen the rate of contamination from many interfering microbes [128]. All these attributes must be put into consideration by the metabolic engineers when trying to develop the most suitable microbe for large scale production of biofuel.

\section{High substrate utilization ability}

The model microbe used for biofuel production must be able to hydrolyze lignocellulosic biomass substrate and produce the desired end products at a high amount under industrial conditions. For a strain to use a high amount of lignocellulosic sugars, several attributes must be put into perspective. Primarily, the strain must be able to achieve a high cell mass growth index in a short time and recovery of biofuel from the biomass-derived hydrolysates that could contain inhibitory substances such as aromatic compounds, acetate, and aldehydes [128]. Furthermore, the ability to use a wide range of sugars such as pentose, hexose, and disaccharides is of great importance in biofuel production. Finding microbes that can achieve such desirable traits can be either through screening or incorporation of such genes [129, 130].

Several groups have reported the use of Saccharomyces cerevisiae and Escherichia coli as engineered industrial strains [131-135]. Most industrial strains do not metabolize other sugars in the presence of glucose because of carbon catabolite repression [136-138], which serves as a limitation for their use with substrates such as lignocellulose. Sievert et al. [137] reported the solution to this restriction by engineering $E$. coli strains with a point mutation in a transcriptional activator for catabolic operons, thus leading to catabolic activation independence of the catabolite repression control [138]. Alternatively, introducing transporters together with gene expression encoding for the utilization of other sugars have also alleviated glucose repression and facilitated co-fermentation [139] This approach had been proven by engineering $E$. coli and yeasts to co-metabolize several combinations of sugars [136].

\section{Good tolerance to inhibitors and end products}

One crucial issue that has to be overcome to reach an optimum yield of biofuel production is to enhance tolerance of strains to inhibitory compounds, metabolic intermediates, and the desired end products [140]. Examples of toxic compounds present in lignocellulosic hydrolysate include furan derivatives, weak organic acids, and phenols. As microbial cell growth is important to increase biofuel production, engineering robust strains with high tolerance to inhibitors is imperative. During microbial fermentation for biofuel production, the accumulation of end products and by-products can negatively affect the growth of microbes, thus impeding the level of production. Consequently, it is imperative to advance tolerance to inhibitors when engineering strains for biofuel production [140, 141].

The engineering of strains to have special features such as high tolerance level to inhibitory compounds is crucial in accomplishing high productivity and sustainable industry. This can be achieved through rational and evolutionary engineering [142]. Rational engineering entails direct manipulation of known genetic components such as transcriptional regulators, transporters, and pathway enzymes identified [140], because of previous knowledge of the mechanisms of toxicity and tolerance. Whilst evolutionary engineering involves indirect manipulation through adaptation or mutagenesis resulting in the evolution of strains, high-throughput screening is used in the selection of strains with high tolerance level [143].

The factors involved in producing enhanced tolerance strains are explicated through using systematic biological techniques, endowing parental strains, and other native strains with the desired tolerance phenotype by genetic exploitations of uncovered target factors [140]. To demonstrate the potential for improving tolerance of microbial strains, Atsumi et al. [144] serially transferred cultures of $E$. coli for enrichment in isobutanol to obtain tolerant strains. After five rounds of culture transfer, an engineered (mutant) strain displayed $2.0 \%$ $(\mathrm{w} / \mathrm{v})$ isobutanol tolerance, whereas the wild type E.coli strain (JCL16) lacked tolerance since 1.5\% (w/v) isobutanol inhibited its activity [144]. Furthermore, tolerance improvement strategies such as global transcription machinery engineering can be used [144]. Most metabolic engineering research involving biofuel production emphasizes enhancing the catalytic effectiveness of a sole reaction. Alper et al. [143] developed a global transcription machinery engineering (gTME) system to enhance glucose/ethanol tolerance in S. cerevisiae. This method entailed reprogramming gene transcription to obtain cellular phenotypes vital for the technological approach. Transcription factor Spt15p was subjected to mutation which brought about a rise in tolerance and more 
effective glucose conversion to bioethanol. The resulting phenotype was from the combination of three different mutations in the Spt15 gene containing Phe177Ser, Tyr195His, and Lys218Arg [143]. Therefore, gTME can provide a channel to complex phenotypic traits that are not readily accessible by conventional approaches. This was recently confirmed by El-Rotail et al. [145] who designed SPT15 mutagenesis library of Saccharomyces cerevisiae using the gTME approach. The authors obtained a novel mutant of $S$. cerevisiae with a higher tolerance to ethanol stress when treated with $3 \% \mathrm{MnCl}_{2}$ in place of the widely used mixture of error-prone (Ep$\mathrm{PCR}$ ) reaction with $\mathrm{MgCl}_{2}$ and yielded the highest ethanol production.

\section{High metabolic fluxes}

One of the constraints experienced by engineered microbial cell factories includes metabolic imbalance as a result of nutrients depletion, metabolite accumulation, evolutionary pressure, genetic instability, or other stress factors [146]. It is of tremendous importance when developing the model strain to be equipped with a sensor-regulator system that will allow the cell to adjust metabolically in response to the surrounding changes [146]. Metabolic fluxes have been greatly manipulated by metabolic engineers to improve the model strain abilities in the production of biofuel [147, 148].

Approaches such as fed-batch cultures, mutagenesis, and optimal control of the metabolic pathways have been developed to cope with the balance between cell density and product formation and to enhance the cost-effectiveness of industrial fermentation [146]. With the aid of metabolite-responsive transcriptional factors [146], metabolic engineers can now engineer cell factories to realize self-adaptation for biotechnological applications. This could be achieved by revamping the transcriptional regulatory networks and aiding the cell to independently regulate pathway expression and modify the metabolic activity to the changing environment $[139,146,149,150]$. Alternatively, the dynamic control theory could be used to maximize pathway efficiency [146, 151]. Xu et al. [152] used this approach by engineering naturally occurring transcriptional regulator FapR to control the fatty acids biosynthetic pathway in E. coli. Fatty acid production is significantly developed by optimum control of gene expression resulting in balanced metabolism between the growth of cells and the formation of products. Application of metabolic control enables the engineered strain to dynamically control pathway expression and balanced the metabolic activity of key enzymes based on the intracellular level activities.

Insight into the complex regulation of metabolic fluxes can be known through the function of three factors in a given biochemical reaction namely (i) enzymatic activity of the catalyzing enzyme (ii) characteristics of the enzyme (iii) the effects of substrates and metabolites on the enzymatic activity. The enzymatic activity exhibited by a strain is due to gene expression, translation, and post-translational protein modifications. The enzyme traits are usually specific for a given biological system under research. However, in situations where the heterologous enzymes are introduced to redirect metabolic fluxes, it becomes imperative to study the traits of the heterologous enzyme in comparison to other enzymes having interaction with the same metabolite pools [146]. Feedback regulation was imposed on the system by the concentration of metabolites and properties of the enzymes which serve important functions in the metabolic fluxes [153].

\section{Bioprospecting for native strains with the gene of interest}

Extensive research has shown that several microbes belonging to the class fungi, yeast, and bacteria can exhibit cellulolytic activity $[24,154]$. Today, the process of bioethanol production exploits cellulolytic enzymes from microbes with some strains having established industrial applications, a high conversion rate of glucose to ethanol and tolerance to end products, and other inhibitory compounds $[6,155]$. However, during their evolution, some of these organisms have not been exposed to the conditions obtainable under industrial settings that typically arise in the industrial processing of feedstock to biofuel.

Screening for a particular trait is one of the most effective ways of discovering novel enzymes applicable to the industry [156]. Native strains produce diverse extracellular and intracellular enzymes naturally that could exhibit activities of industrial importance. One of the common methods used for finding these strains is bioprospecting. Bioprospecting involves screening native strains isolated from diverse sources for novel and functional enzymes which might be relevant. These microorganisms are isolated from different environments and are explored for their ability to utilize certain substrates for biofuel production [157]. Consequently, the selection of the best candidate is based on the high production of the desired end products. Another approach is probing the genome contents of environmental samples through metagenomics. The use of probes and primers specific to target certain gene(s) of industrial importance $[158,159]$.

The main drawback of this approach is that it is qualitative: the metabolic perspective cannot be quantified because isolation and culturing of the microbe cannot be achieved [159]. Analyzing the genetic make-up of the strains helps in the prospecting of potential microorganisms very quickly, which facilitates the evaluation of the proteome of the microbes and to determine if the isolate 
possesses the gene(s) of interest. Besides, the bioprospection of genes of interest by metagenomic strategies allows the identification of uncultured microorganisms [160, 161].

Bioprospecting contributes significantly to the advancement of biofuel production. For instance, the isolation of extremophiles from exotic locations leading to successive extraction of interesting enzymes. Using such microorganisms is advantageous in the sense that they can produce special enzymes that can withstand different industrial conditions such as high temperature, salinity, and pressure [162]. One of the major benefits of exploiting enzymes from hyperthermophiles is the reduction of contaminants from the operating system. Besides, high temperatures also result in very low viscosity and increase the solubility of substrates, ultimately leading to high yields as a result of favorable displacement of the equilibrium in endothermic reactions [159]. The successful use of native strains to produce biofuel entails having a better insight into their physiology under various conditions and subsequent strain improvements.

\section{Process of fermentation using metabolic engineered strains}

The lignocellulosic biomass can be fermented by several microbes $[116,126]$ but the complete utilization of lignocellulosic biomass for the production of biofuel is impeded by the lack of model strains that could effectively degrade both pentose and hexose sugars to glucose [25]. An ideal industrial strain sustainable for commercial production of biofuel should use a wide variety of substrates, produce a higher yield of end products, tolerate high levels of end and by-products, and high temperature, should be able to withstand inhibitory compounds and have high cellulolytic activity [163-165]. Moreover, microbial hosts should exhibit sturdiness against stresses and toxic chemicals, and scale-up, and actual commercialization of advanced biofuels.

Metabolic engineering has been used to modify native strains increasing the production of biofuels. The production of biofuel has been developed from a variety of biomass feedstocks (from starch-based to lignocellulose) by engineering or developing the metabolic pathways of diverse microbial hosts [166-168]. The concept of metabolic engineering with the aid of recombinant DNA technology, brought about the improvement of biosynthesis of desired products by the exploitation of biosynthetic pathways, transport systems, and regulatory functions of the cell [169]. Genetic engineering employed the use of classical mutagenesis and selection and recombinant methods for the over-expression of the desired end product during the process of fermentation associated with pathways. Strains are engineered in the laboratory to make them tolerant to high concentrations of end products and other inhibitory substances by removing the normal regulatory genes and enzymes associated with the metabolic pathway. The ultimate goal is to develop a robust fermentation process that facilitates the high production of the desired product(s) with little or no bottleneck.

For metabolic engineering of the strain to be regarded as being successful, the whole process must be costeffective on a large scale. To achieve this, researchers had to develop novel techniques such as whole-genome sequencing, bioinformatics, systems biology, proteomics, and metabolomics. All these techniques have significantly assisted researchers in enhancing the applications of metabolic engineering over the past years. These have helped in developing novel engineered strains that can carry out high-throughput performance using renewable feedstocks such as lignocellulose, rationalizing production cost even more.

Production of higher octane hydrocarbons which are substitutes to ethanol such as 1-butanol, isobutanol, and isopentanol, with improved fuel qualities, are biosynthesized through engineering fermentative pathways, non-fermentative keto acid pathways, and isoprenoid pathways [170-172]. Amongst higher alcohols, fattyacid-derived and isoprenoids-derived biofuel from microorganisms have also been suggested as superior fuel alternates. Several native isolates and their metabolic pathways have been investigated comprehensively to improve yield, titer, productivity and to reduce the cost of production using various strategies [173-178]. The application of genetic and metabolic engineering approaches have led to significant advancement by improving existing applications and also opening up new possibilities $[179,180]$. These approaches have improved the physiology of the potential producers of biofuel, enabling high and cost-effective production. Due to different mechanisms of action within the hosts, it would be difficult to ascertain a conventional approach that will work for the different types of biofuels obtained from diverse metabolic pathways [181, 182]. Heavy reliance on fossil fuel and the effect of global warming can be reduced by providing environmental-friendly energy to power automobiles and other industrial appliances.

Most of these difficulties can be addressed by tailoring the redesigned metabolic system of each microorganism to suit the end product in other to advance yield and productivity, and ultimately reduce operating cost [180]. A successful outcome from genetic engineering can translate to effective land use and biodiversity. For instance, the maximum production of biofuel from lignocellulosic biomass feedstock corresponds to an equal saving in land usage because fewer raw materials are needed. Metabolic 
engineering of microorganisms to make use of various feedstocks effectively can as well sustain native flora by decreasing the need for requiring non-native plants [183].

Metabolic pathways can be engineered to biosynthesize new products that can replace fossil fuel including long octane numbers short-chain, branched-chain, and cyclic alcohols, alkanes, alkenes, esters, and aromatics compounds. Understanding the need for superior fuel is of importance to develop strains that will produce alternate biofuel with useful applications [19]. One of the major shortcomings in these processes is how to enhance carbon assimilation in the metabolic pathways and then control the fluxes of these pathways to biosynthesize product(s) interest either by natural or engineered pathways [183]. Many of these desired products are sought after because of their outstanding qualities for more specialized applications. Nevertheless, while some of these compounds or their precursors can be biosynthesized from diverse metabolic pathways that exist naturally in microorganisms, these pathways often need to be optimized or redesigned to advance effectiveness. Moreover, practical or theoretical yields are calculated based on biosynthetic pathways and levels of productivity. The unavailability of genetic engineering platforms for native isolates, coupled with challenges in the optimization of the metabolic pathways, and balancing the redox state in engineered strains are major drawbacks to the development of low-cost industrial processes for the conversion of lignocellulosic biomass feedstocks into biofuel [19, 103]. The engineering of biosynthesis pathways in native strains can bring about an increase in biofuel formation. For instance, the engineering of electron metabolism in Clostridium thermocellum increased bioethanol production [184]. Several metabolic engineered strains of microbes have been used successfully for biofuel production (Table 2).

Through the manipulation of the genetics and metabolic pathways of microorganism, scientists have been able to enhance the production of specific metabolites which have been used successfully in the production of biofuel and other products. For instance, Zymomonas

Table 2 Metabolic engineered strains of microorganisms used for biofuel production

\begin{tabular}{|c|c|c|c|c|}
\hline Organisms & Product & Pathway & Substrate & References \\
\hline Corynebacterium glutamicum & 3-Hydroxypropic acid & Glycerol & Glucose, xylose & [185] \\
\hline Clostridium autoethanogenum & Ethanol & Ferredoxin oxidoreductase & Synthetic medium & [186] \\
\hline Synechocystis sp. & Isobutanol & Ehrlich & Glucose & [187] \\
\hline S. elongates & 1,3-Propanediol & Synthetic metabolic pathway & Synthetic medium & [188] \\
\hline E. coli & Fatty alcohol & Fatty acyl-ACP reductase-dependent & Synthetic medium & [189] \\
\hline Saccharomyces cerevisiae & 2,3-Butanediol & Butanediol biosynthetic & Glucose, galactose & [190] \\
\hline Klebsiella pneumoniae & 2-Butanol & Meso-2,3-butanediol synthesis & Glucose & [191] \\
\hline C. cellulolyticum & n-Butanol & CoA-dependent & Cellulose & [15] \\
\hline Thermoanaerobacterium saccharolyticum & n-Butanol & n-butanol & Xylose & [232] \\
\hline Enterobacter cloacae & 2,3-Butanediol & Pentose phosphate & Lignocellulose & [192] \\
\hline Methylobacterium extorqens & 1-Butanol & Ethyl malonyl-CoA & Ethylamine & [193] \\
\hline C. cellulovorans & Ethanol, n-Butanol & Fatty acyl-ACP reductase-dependent & Cellulose & [194] \\
\hline Caldicellulosiruptor & Hydrogen & Glycolytic & Lignocellulose & [195] \\
\hline \multicolumn{5}{|l|}{ Bescii } \\
\hline S. cerevisiae & Isobutanol & Embden-Meyerhof & Synthetic medium & [196] \\
\hline S. cerevisiae & n-Butanol & $\begin{array}{l}\text { Clostridial acetoacetyl-CoA-derived } \\
\text { pathway }\end{array}$ & Synthetic minimal & [197] \\
\hline S. cerevisiae strain XUSAE57 & Ethanol & Xylose-isomerase pathway & Xylose and Glucose & [198] \\
\hline Clostridium Tyrobutyricum & n-Butanol & Xylose metabolic pathway & Glucose and Xylose & [199] \\
\hline $\begin{array}{l}\text { Clostridium acetobutylicum and Saccharo- } \\
\text { myces cerevisiae }\end{array}$ & n-Butanol & $\begin{array}{l}\text { Clostridial acetoacetyl-CoA-derived } \\
\text { pathway }\end{array}$ & $\begin{array}{l}\text { Glucose, corn, } \\
\text { starch, and corn } \\
\text { stover }\end{array}$ & {$[200,201]$} \\
\hline $\begin{array}{l}\text { Clostridium thermocellum and Thermoan- } \\
\text { aerobacterium saccharolyticum }\end{array}$ & Ethanol & Embden-Meyerhof & Cellulose & [202] \\
\hline \multirow[t]{2}{*}{ E. coli } & 1-butanol, & 2-keto acid degradation pathway & Glucose & [144] \\
\hline & $\begin{array}{l}\text { 2-methyl-1-butanol, } \\
\text { 3-methyl-1-butanol, } \\
\text { 2-phenylethanol }\end{array}$ & & & \\
\hline
\end{tabular}


mobilis a well-known indigenous producer of bioethanol can only efficiently utilize hexose sugar (glucose) converting it to bioethanol compared to Saccharomyces cerevisiae but not from pentose sugars. This is a major drawback in its utilization for biofuel production from lignocellulose biomasses which are rich in pentose sugars. Zymomonas mobilis lacks a complete pentose phosphate pathway due to the absence of transaldolase activity [203] Z. mobilis uses the Entner-Doudoroff (ED) pathway which is more efficient than the Embden-Meyerhof-Parnas (EMP) pathway utilized by S. cerevisiae with less use of ATP [204] To circumvent this challenge, a metabolic engineering approach was used to enable $Z$. mobilis to utilize pentose sugar by introduction and expression of genes encoding the enzymes xylose isomerase, xylulokinase, transaldolase and transketolase which created a complete metabolic pathway for the conversion of xylose to important intermediates of the EMP pathway (glyceraldehyde -3-phosphate and fructose-6-phosphate) leading to bioethanol production (Fig. 4).

The xylose fermenting strain of $Z$. mobilis was constructed by cloning Escherichia coli $x y l A$ and $x y l B$ genes using a potent $Z$. mobilis glyceraldehyde-3-phosphate promoter by PCR-mediated overlap extension [203]. $Z$ mobilis was transformed with the xylose assimilation operon obtained but the transformants still could not utilize xylose in the medium due to lack of sufficient transketolase and transaldolase activities [203]. Therefore, an open reading frame that encodes transaldolase tal gene on E. coli was synthesized using PCR and subsequently subcloned using a $Z$ mobilis enolase promoter by PCR- mediated overlap extension. Likewise, a transketolase gene $(t k t A)$ was synthesized from $E$ coli W3110 genomic DNA and subcloned immediately downstream of the transaldolase homolog translation codon giving rise to an operon that encodes the nonoxidative part of the pentose phosphate pathway [203]. The xylose assimilation and pentose phosphate pathway operons constructed were concurrently transferred into $Z$ mobilis CP4 using a $Z$ mobilis pACYC184. The recombinant $Z$ mobilis CP4 (pZB5) grew on xylose containing medium and produced a yield of $86 \%$ and $94 \%$ ethanol from xylose and glucose respectively [203]. Recently an improved strain of Z. mobilis TMY-HFPX was developed containing an operon with several genes $x y l A$ / $x l y B / t k t A / t a l B$ for the utilization of xylose, the metB/ yfdZ operon for lysine and methionine biosynthesis, the thioesterase gene tesA which improves free fatty acid biosynthesis for higher ethanol tolerance, a protonbuffering peptide operon for acid stress tolerance, and a small heat shock protein operon for heat stress tolerance [205]. This strain gave a theoretical yield of $90 \%$ ethanol from the utilization of xylose as the carbon source [205] Metabolic engineering has also been used to enhance

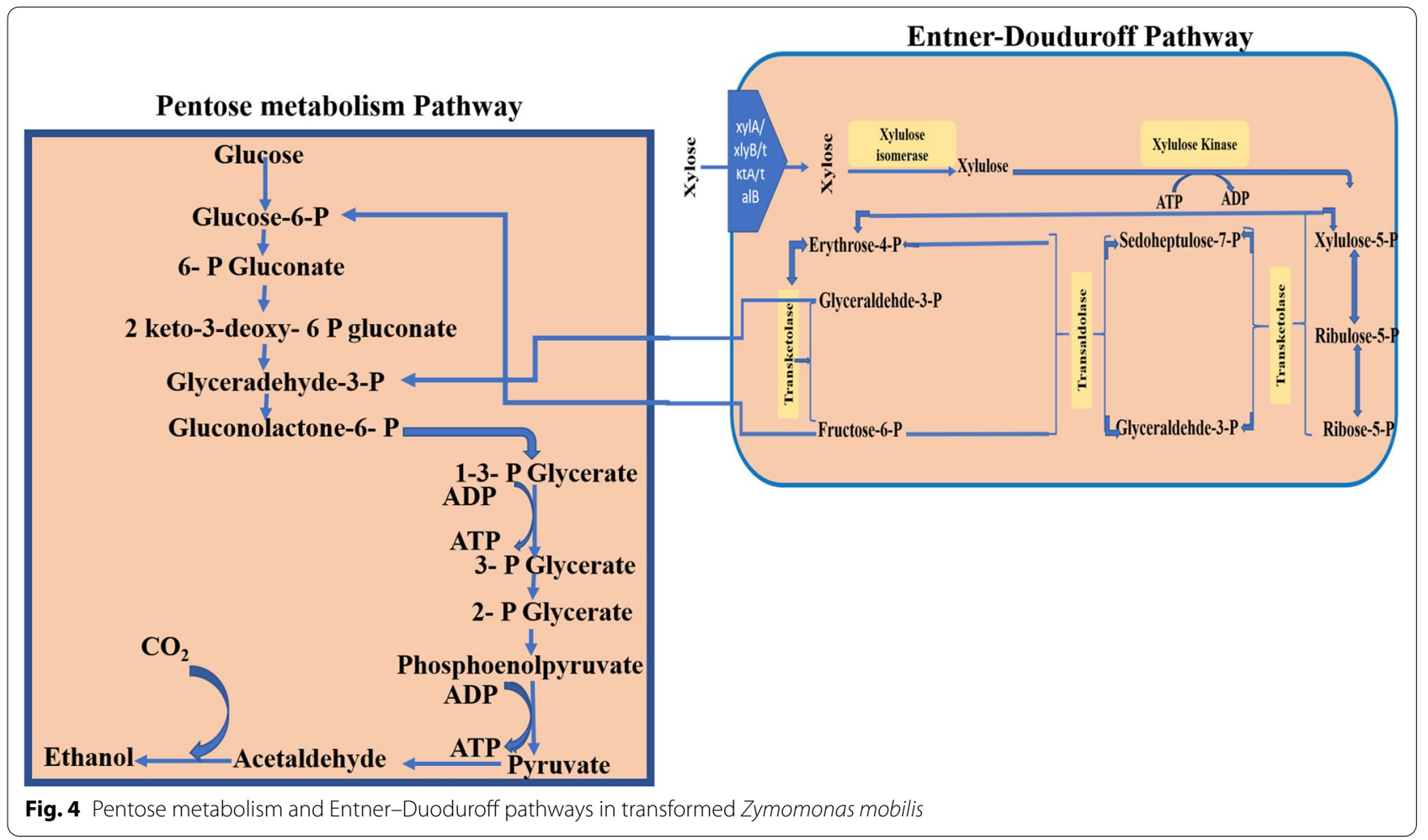


biofuel production abilities of several other microorganisms, including Bacillus subtilis for ethanol production, Clostridium for butanol production as well as E.coil. B. subtilis strain BS35 was designed by obstructing the lactate dehydrogenase gene via chromosomal insertion of the $Z$. mobilis pyruvate decarboxylase gene and alcohol dehydrogenase II gene controlled by the ldh native promoter $[204,206]$. Although the strain yielded ethanol and butanediol, compared to the wild type, the transformed strain had reduced cell growth and glucose utilization up to $60-70 \%$. Nevertheless, further manipulation of the BS35 to BS36 (BS35 $\Delta a l s S$ ) resulted in 89\% theoretical yield of ethanol, and by inactivation of als $S$ through chromosomal integration of $E$. coli transhydrogenase gene, a new strain BS37 (BS35 $\Delta a l s S u d h A^{+}$) capable of producing $8.9 \mathrm{gL}^{-1}$ ethanol was obtained [206].

Klebsiella pneumoniae HR526 a high yielding 2,3-butanediol producing strain was engineered by Chen et al. [191] for the production of 2-butanol. The authors extended the 2,3-butanediol synthesis pathway of the bacterium and introduced diol dehydratases and alcohol dehydrogenases. Optimization of the pathway and engineering of the diol dehydratase via protein engineering resulted in an increased yield of 2-butanol $(1030 \mathrm{mg} / \mathrm{L})$. In another study, metabolic engineering of cellulolytic Clostridium cellulovorans with the genes for aldehyde/ alcohol dehydrogenase (adhE2) and an artificial electron carrier methyl viologen (MV) was carried out by Yang et al. [194], in a bid to directly produce ethanol and $\mathrm{n}$-butanol at a higher rate from cellulose. The adhE2 gene from Clostridium acetobutylicum was fully expressed in C. cellulovorans which led to the production of considerable quantities of $\mathrm{n}$-butanol $(1.42 \mathrm{~g} / \mathrm{L})$ and ethanol $(1.60 \mathrm{~g} / \mathrm{L})$ from the crystalline cellulose [194]. C. cellulovorans is a very useful bacterium for metabolic engineering due to its ability to utilize several substrates and also possesses numerous cellulosomal genes [194, 207]. Recently Bao et al. [208] went a step further to introduce two extra aldehyde/alcohol dehydrogenases encoded by $b d h B, a d h E 1$ in addition to $a d h E 2$ used by Yang et al. [194] from C. acetobutylicum into C. cellulovorans. Coexpression of either adhE1 or adhE2 with $b d h B$ genes failed to improve the yield of butanol possibly due to the limiting factor of NADPH in C. cellulovorans [194]. The highest yield of butanol was obtained only by the strain overexpressing adhE2 (4.0 g/L) which was $181.69 \%$ times higher than the amount recorded by Yang et al. [194]. Acetic acid is known to disrupt the efficiency of microbes such as Saccharomyces cerevisiae during the fermentation process, thereby reducing their bioconversion ability of lignocellulosic biomass to produce biofuel. This recently led Ko et al. [198] to engineer a high xylose utilizing strain of Saccharomyces cerevisiae XUSAE57 for enhanced bioethanol production by improving tolerance to acetic acid. This strain was chosen out of the several variants obtained from culturing a previously engineered S. cerevisiae strain possessing the xylose-isomerase pathway XUSE developed by PTN Hoang, Ko et al. [209]. This served as the parental strain and was cultured with the adapted XUSAE57 strains in yeast synthetic complete media (YSC) containing $20 \mathrm{~g} / \mathrm{L}$ xylose, incubated aerobically at $30^{\circ} \mathrm{C}$ for 1.5 days for preculture and subsequently in fresh YSC medium containing $20 \mathrm{~g} / \mathrm{L}$ xylose and $0-5 \mathrm{~g} / \mathrm{L}$ acetic acid with an initial $\mathrm{pH}$ of 5 [198]. This resulted in a twofold increase in ethanol production, in addition to a twofold increase in xylose utilization in contrast to the XUSE strain in the presence of $4 \mathrm{~g} / \mathrm{L}$ of acetic acid [198]. Besides, the improved XUSAE57 strain till date, has the highest amount ethanol produced from the bioconversion of glucose and xylose from lignocellulose hydrosylate). Metabolic engineering of useful microbial strains will definitely have a great impact on the biofuel industry in the nearest future. This will, however, require identification of useful strains and having a mechanistic understanding of the various metabolic pathways that can be harnessed for better biofuel production.

\section{Future prospects}

Microbial metabolic engineering is not an easy task, especially for the identification of efficient strains, but it is indispensable for the advancement of the biofuel production industries. The important metabolic pathways must be well understood, and the relevant enzymes identified. The limiting regions of pathways are being identified by metabolic engineers and synthetic biologists using different approaches [204, 210-212]. The process of metabolic engineering for enhancing recombinant protein expression keeps on evolving and becoming sophisticated. Industrial microbes have been modified or designed to improve recombinant metabolite productivity while saving time and money [204, 213, 214].

Advanced technologies such as clustered regularly interspaced short palindromic repeats (CRISPR)/Cas9 is being used to accelerate genetic engineering of microbes as it permits rapid and efficient editing of the genome by replacing 20-nucleotide sequences of a chimeric single-guide RNA (sgRNA) complementary to the target sequence of interest [215]. Immediately, the Cas9-sgRNA complex binds to the target DNA sequence, the endonuclease activity of the CRISPR-associated protein (Cas9 protein) cleaves the DNA [215]. This hastens metabolic engineering of proteins and editing of useful genes that could enhance tolerance to inhibitors, or promote utilization of different substrates used for biofuel production. The mechanism and major components of the Streptococcus pyogenes Type II CRISPR-Cas9 system have been well 
characterized. It consists of a Cas9 protein with endonuclease activity which is guided by two types of small RNAs, a target-recognizing CRISPR RNA (crRNA) which binds the target DNA and guides cleavage, and auxiliary non-coding trans-activating crRNAs (tracrRNAs) which base-pairs with the crRNA and permits the formation of Cas9-crRNA complex [216-219]. Genes relevant to biofuel-producing bacterial strains could be edited for better performances, novel genes inserted, or unwanted genes deleted or knocked out. For the activation of specific genes, CRISPR activation (CRISPRa) system is used. In this case, the $\mathrm{dCas} 9$ is fused to transcription activators such as RNA Polymerase u subunit present in bacterium such as Escherichia coli. To knockout unwanted genes another approach known as CRISPR interference (CRIS$\mathrm{PRi}$ ) which has an inactivated endonuclease activity, is utilized. A catalytically dead Cas9 (dCas9) forms a complex with sgRNA which inhibits RNA polymerase resulting in the blockage of transcription. This arises due to the binding of the dCas9-sgRNA complex to the upstream region of the target gene sequence. Besides, the nucleasedeactivated Cas9 possessing only DNA-binding function guided by sgRNA, has revealed the potential to control regulatory functions in gene expression [220-222]. The CRISPR-Cas9 technology is naturally used by prokaryotes as a defensive mechanism against foreign nucleic acids from viruses or any foreign DNA. Thus, using the CRISPRa and CRISPRi gene-editing technologies, the expression of endogenous genes can be either up-regulated or down-regulated, making it easier for researchers to effectively study the function of genes relevant to metabolic pathways required for biofuel production.

CRISPR-Cas 9 is revolutionizing the science of genetic engineering, and metabolic engineering. Its utilization in genome editing has surpassed that of previous tools such as zinc finger nucleases (ZFNs) and transcription-activator-like effector nucleases (TALENs) previously applied for the genetic manipulation of bacteria $[223,224]$. It is now widely used as a genomeediting tool since it is based on RNA-DNA recognition using highly specific 20-nucleotides guide RNA for directing the Cas9 towards the specific site [201]. The versatility of the CRISPR/Cas9 technology is shown by the ease with which it is engineered to enhance the simultaneous targeting of multiple genes for developing potent strains [224, 225]. Several biofuels and other commercial products have been produced by the use of CRISPR-based methods [201, 226]. The CRISPR/ Cas9 systems have been employed in the manipulation of genes in several bacterial cells belonging to the genera Bacillus, Clostridium, Corynebacterium, Escherichia coli, Lactobacillus, Mycobacterium, Pseudomonas,
Staphylococcus, and Streptomyces [215]. With this technology, several genetically modified microorganisms with high biofuel-producing abilities have been obtained.

The CRISPR/Cas 9 system was recently used to engineer a dual-operon-based synthetic pathway in the genome of Escherichia coli strain MG1655, which produced $5.4 \mathrm{~g} / \mathrm{L} \mathrm{n}$-butanol in a medium containing glucose as the carbon source and subsequently repeated in an ethanologenic strain of $E$. coli strain SSK42 to produce butanol from xylose using a redoxbalanced pathway by Abdelaal et al. [227]. A synthetic butanol cassette was integrated into the genome of $E$. coli strain SSK42 through CRISPR/Cas9 system after removal of the gene encoding endogenous ethanol production. The newly engineered strain ASA02, generated $4.32 \mathrm{~g} / \mathrm{L}$ butanol in fed-batch fermentation process [227]. Clostridium saccharoperbutylacetonicum N1-4 a recognized hyperbutanol-producing strain was edited by targeting two important genes: $p t a$ and $b u k$, which encodes for acetate and butyrate production [228]. Increased butanol production, higher yield, and selectivity of mutants in the batch fermentation were obtained, but this was dependent on the fermentation medium used. The highest butanol yield in the batch fermentation process was obtained in the P2 medium with a yield of $19.0 \mathrm{~g} /$ liter [228]. The efficiency was improved using the PJ23119 promoter to guide RNA (gRNA) expression [228]. In another study, Wasels et al. [229] designed a dual plasmid-inducible CRISPR/ Cas9 genome editing tool for the solventogenic strain Clostridium acetobutylicum ATCC 824, which led to mutants that produced an isopropanol-butanol-ethanol mixture. Despite the benefits derived from the CRIPSER/Cas9 system in recent times, it requires much expertise and is still in its nascent stage in metabolic engineering, especially in the developing countries.

Advances in high-throughput technologies such as proteomics, transcriptomics, and metabolomics are increasingly been used to understand how specific genes are expressed and the role they play in metabolic pathways associated with biofuel production by lignocellulose degrading microorganisms [230, 231]. Computational tools are often used to obtain a mechanistic understanding of the information derived from these advanced technologies. The use of principal component analysis proteomics-guided engineering led to an improvement in the production of two terpenes by more than $40 \%$ via the heterologous mevalonate pathway in E. coli [231]. These computational tools and advanced technologies should be fully harnessed for the screening and metabolic 
engineering of microbial strains for improved industrial production of biofuel.

\section{Conclusion}

Microorganisms are major players in the production of biofuel. However, the product's yield by native strains is not economical, thus making it necessary to develop and improve them through the approach of metabolic engineering and genetic engineering. Recent studies have focused on applying metabolic engineering to model strain development to optimize high productivity and energy value at a cheaper cost of production. In the nearest future, there is a high possibility that more unique metabolic pathways for biofuel production could emerge from database mining. Thus, the implementation of these pathways in industrial fermentation hosts may overcome any bottlenecks associated with the use of lignocellulosic biomass as a renewable fermentation feedstock. Metabolic engineers need to tap into the use of advanced technologies currently available such as the omic technologies and CRISPER/Cas9 system to design and generate novel strains of microbes with enhanced ability to produce biofuel from diverse substrates by insertion of relevant genes into the genome or deletion of obstructive ones.

\section{Acknowledgements}

The researchers would like to thank the National Research Foundation, South Africa for NRF scarce skill postdoctoral fellowship (SFP150731133595) to MFA and NRF grant (UID91990) to OOB., PT acknowledges CONICET as a career research member and the Instituto Nacional de Tecnología Agropecuaria (INTA) (PNAlyAV-1130034).

\section{Author contributions}

All authors read and approved the final manuscript.

Funding

Not applicable.

\section{Availability of data and materials}

Not applicable.

Ethics approval and consent to participate

Not applicable.

\section{Consent for publication}

Not applicable.

\section{Competing interests}

The authors declare that they have no competing interests.

\section{Author details \\ ${ }^{1}$ Food Security and Safety Niche Area, Faculty of Natural and Agricultural Sciences, North-West University, Mmabatho, Private Bag X2046, 2735, South Africa. ${ }^{2}$ Department of Biological Sciences, Faculty of Science, Kings Univer- sity, Ode-Omu, PMB 555, Osun State, Nigeria. ${ }^{3}$ Instituto de Agrobiotecnología y Biología Molecular (IABIMO), Instituto Nacional de Tecnología Agropecuaria (INTA CICVyA, CNIA, INTA Castelar, Dr. N. Repetto y Los Reseros s/n, (1686) Hurl- ingham, 1686) Hurlingham, Provincia de Buenos Aires, Argentina. ${ }^{4}$ Consejo Nacional de Investigaciones Científicas Y Tecnológicas (CONICET), Buenos Aires, Provincia de Buenos Aires, Argentina.}

Received: 4 June 2020 Accepted: 9 December 2020 Published online: 06 January 2021
References

1. Lan El, Dekishima Y, Chuang DS, Liao JC. Metabolic engineering of 2-pentanone synthesis in Escherichia coli. AlChE J. 2013;59(9):3167-75.

2. Pandey A, Larroche C, Gnansounou E, Khanal SK, Dussap C-G, Ricke S: Biofuels: alternative feedstocks and conversion processes for the production of liquid and gaseous biofuels. 2019.

3. Ben-Iwo J, Manovic V, Longhurst P. Biomass resources and biofuels potential for the production of transportation fuels in Nigeria. Renew Sustain Energy Rev. 2016;63:172-92.

4. Naik SN, Goud VV, Rout PK, Dalai AK. Production of first and second generation biofuels: a comprehensive review. Renew Sustain Energy Rev. 2010;14(2):578-97.

5. Adegboye MF, Lobb B, Babalola OO, Doxey AC, Ma K. Draft genome sequences of two novel cellulolytic streptomyces strains isolated from South African rhizosphere soil. Genome Announc. 2018;6(26):e00632-e1618.

6. Banerjee G, Scott-Craig JS, Walton JD. Improving enzymes for biomass conversion: a basic research perspective. Bioenergy Res. 2010;3(1):82-92.

7. Chubukov V, Mukhopadhyay A, Petzold CJ, Keasling JD, Martín HG. Synthetic and systems biology for microbial production of commodity chemicals. Syst Biol Appl. 2016;2:16009.

8. Griffiths H: Bringing New Products from Marine Microorganisms to the Market. The marine microbiome. Springer; 2016. p. 435-452.

9. Ahmed AAQ, Babalola OO, McKay T. Cellulase- and xylanase-producing bacterial isolates with the ability to saccharify wheat straw and their potential use in the production of pharmaceuticals and chemicals from lignocellulosic materials. Waste Biomass Valorization. 2018;9(5):765-75.

10. Ceballos R, Chan M, Batchenkova N, Duffing-Romero A, Nelson A, Man S. Bioethanol: feedstock alternatives, pretreatments, lignin chemistry, and the potential for green value-added lignin co-products. J Environ Anal Chem. 2015. https://doi.org/10.4172/2380-2391.1000164.

11. Taha M, Foda M, Shahsavari E, Aburto-Medina A, Adetutu E, Ball A. Commercial feasibility of lignocellulose biodegradation: possibilities and challenges. Curr Opin Biotechnol. 2016;38:190-7.

12. Liu G, Zhang J, Bao J. Cost evaluation of cellulase enzyme for industrialscale cellulosic ethanol production based on rigorous Aspen Plus modeling. Bioprocess Biosyst Eng. 2016;39(1):133-40.

13. Aro E-M. From first generation biofuels to advanced solar biofuels. Ambio. 2016;45(1):24-31.

14. Abomohra AE-F, Jin W, Tu R, Han S-F, Eid M, Eladel H. Microalgal biomass production as a sustainable feedstock for biodiesel: current status and perspectives. Renew Sustain Energy Rev. 2016, 64:596-606.

15. Gaida SM, Liedtke A, Jentges AHW, Engels B, Jennewein S. Metabolic engineering of Clostridium cellulolyticum for the production of n-butanol from crystalline cellulose. Microb Cell Fact. 2016. https://doi. org/10.1186/s12934-12015-10406-12932.

16. Peralta-Yahya PP, Zhang F, Del Cardayre SB, Keasling JD. Microbial engineering for the production of advanced biofuels. Nature. 2012;488(7411):320-8.

17. Pirie CM, De Mey M, Prather KLJ, Ajikumar PK. Integrating the protein and metabolic engineering toolkits for next-generation chemical biosynthesis. ACS Chem Biol. 2013;8(4):662-72.

18. Simeonidis E, Price ND. Genome-scale modeling for metabolic engineering. J Ind Microbiol Biotechnol. 2015;42(3):327-38.

19. Lee SK, Chou H, Ham TS, Lee TS, Keasling JD. Metabolic engineering of microorganisms for biofuels production: from bugs to synthetic biology to fuels. Curr Opin Biotechnol. 2008;19(6):556-63.

20. Jönsson LJ, Alriksson B, Nilvebrant N-O. Bioconversion of lignocellulose: inhibitors and detoxification. Biotechnol Biofuels. 2013;6(1):16.

21. Monshizadeh A. Influence of the molecular weight of cellulose on the solubility in ionic liquid-water mixtures. 2015.

22. Gupta VK, Tuohy K. Microbial enzymes in bioconversions of biomass: Springer; 2016.

23. Nanda S, Mohammad J, Reddy SN, Kozinski JA, Dalai AK. Pathways of lignocellulosic biomass conversion to renewable fuels. Biomass Conversion Biorefinery. 2014;4(2):157-91.

24. Limayem A, Ricke SC. Lignocellulosic biomass for bioethanol production: current perspectives, potential issues and future prospects. Prog Energy Combust Sci. 2012;38(4):449-67. 
25. Sarkar N, Ghosh SK, Bannerjee S, Aikat K. Bioethanol production from agricultural wastes: an overview. Renewable Energy. 2012;37(1):19-27.

26. Safaai M, Sharliza N, Azizan A, Ramli M, Kamarludin C, Norsyarahah S. Overview on mechanical-chemical ionic liquid pretreatment study on bioethanol-based lignocellulosics biomass. Adv Mater Res. 2015; pp. 260-265.

27. Obeng EM, Adam SNN, Budiman C, Ongkudon CM, Maas R, Jose J. Lignocellulases: a review of emerging and developing enzymes, systems, and practices. Bioresources Bioprocessing. 2017;4(1):16

28. Chanliaud E, De Silva J, Strongitharm B, Jeronimidis G, Gidley MJ. Mechanical effects of plant cell wall enzymes on cellulose/xyloglucan composites. Plant J. 2004;38(1):27-37.

29. Babalola OO. Pectinase and cellulase enhance the control of Abutilon theophrasti by Colletotrichum coccodes. Biocontrol Sci Tech. 2007;17(1):53-61.

30. Lynd LR, Cushman JH, Nichols RJ, Wyman CE. Fuel ethanol from cellulosic biomass. Science. 1991;251(4999):1318-23.

31. Rowell RM, Schultz TP, Narayan R. Emerging technologies for materials and chemicals from biomass; 1992.

32. Tsegaye B, Balomajumder C, Roy P. Microbial delignification and hydrolysis of lignocellulosic biomass to enhance biofuel production: an overview and future prospect. In. 2019:43:1-16.

33. Atreya ME. Engineering cellulase enzymes for bioenergy. 2015.

34. Wilson DB. Cellulases and biofuels. Curr Opin Biotechnol. 2009;20(3):295-9.

35. Souza WRd. Microbial degradation of lignocellulosic biomass. 2013.

36. Andlar M, Rezić T, Marđetko N, Kracher D, Ludwig R, Šantek B. Lignocellulose degradation: an overview of fungi and fungal enzymes involved in lignocellulose degradation. Eng Life Sci. 2018;18(11):768-78.

37. Uchida H, Kusakabe I, Kawabata Y, Ono T, Murakami K. Production of xylose from xylan with intracellular enzyme system of Aspergillus niger 5-16. J Ferment Bioeng. 1992;74(3):153-8.

38. Geiser E, Wierckx N, Zimmermann M, Blank LM. Identification of an endo-1, 4-beta-xylanase of Ustilago maydis. BMC Biotechnol. 2013;13(1):59

39. Juturu V, Wu JC. Microbial cellulases: engineering, production and applications. Renew Sustain Energy Rev. 2014;33(33):188-203.

40. Wilson DB. Processive cellulases in: direct microbial conversion of biomass to advanced biofuels. department of molecular biology and genetics, Cornell University, Ithaca. 2015. pp. 83-89.

41. Nam KH, Sung MW, Hwang KY. Structural insights into the substrate recognition properties of $\beta$-glucosidase. Biochem Biophys Res Commun. 2010;391(1):1131-5

42. Biely P, Vršanská M, Tenkanen M, Kluepfel D. Endo- $\beta-1,4-x y l a-$ nase families: differences in catalytic properties. J Biotechnol. 1997;57(1-3):151-66.

43. van den Brink J, de Vries RP. Fungal enzyme sets for plant polysaccharide degradation. Appl Microbiol Biotechnol. 2011;91(6):1477.

44. de Souza WR. Microbial degradation of lignocellulosic biomass. Sustainable degradation lignocellulosic biomass-techniques, applications commercialization 2013. pp. 207-247.

45. Biswas R. Bioprocessing of renewable resources to commodity bioproducts 1 ed VS Bisaria and A Kondo. Production of Cellulolytic Enzymes. Wiley; 2014

46. Bhardwaj N, Kumar B, Verma P. A detailed overview of xylanases: an emerging biomolecule for current and future prospective. Bioresources Bioprocessing. 2019;6(1):40.

47. Benedetti M, Locci F, Gramegna G, Sestili F, Savatin DV. Green production and biotechnological applications of cell wall lytic enzymes. App Sci. 2019;9(23):5012

48. Garg G, Singh A, Kaur A, Singh R, Kaur J, Mahajan R. Microbial pectinases: an ecofriendly tool of nature for industries. Biotech. 2016;6(1):47.

49. Rha E, Park HJ, Kim MO, Chung YR, Lee C-W, Kim JW. Expression of exo-polygalacturonases in Botrytis cinerea. FEMS Microbiol Lett. 2001;201(1):105-9.

50. Mojsov K. Aspergillus enzymes for food industries. New and future developments in microbial biotechnology and bioengineering. Elsevier; 2016. pp. 215-222.

51. Eijsink VG, Petrovic D, Forsberg Z, Mekasha S, Røhr ÅK, Várnai A, Bissaro $B$, Vaaje-Kolstad G. On the functional characterization of lytic polysaccharide monooxygenases (LPMOs). Biotechnol Biofuels. 2019;12(1):58.
52. Meier KK, Jones SM, Kaper T, Hansson H, Koetsier MJ, Karkehabadi S, Solomon El, Sandgren M, Kelemen B. Oxygen activation by Cu LPMOs in recalcitrant carbohydrate polysaccharide conversion to monomer sugars. Chem Rev. 2017;118(5):2593-635.

53. Loose JS, Arntzen M $\varnothing$, Bissaro B, Ludwig R, Eijsink VG, Vaaje-Kolstad G. Multipoint precision binding of substrate protects lytic polysaccharide monooxygenases from self-destructive off-pathway processes. Biochemistry. 2018;57(28):4114-24.

54. Du L, Ma L, Ma Q, Guo G, Han X, Xiao D. Hydrolytic boosting of lignocellulosic biomass by a fungal lytic polysaccharide monooxygenase, AnLPMO15g from Aspergillus niger. Ind Crops Prod. 2018;126:309-15.

55. Raguz S, Yaguea E, Wood D, Thurston C. Isolation and characterization of a cellulose-growth-specific gene from Agaricus bisporus. Gene. 1992;119(2):183-90

56. Armesilla AL, Thurston CF, Yagüe E. CEL1: a novel cellulose binding protein secreted by Agaricus bisporus during growth on crystalline cellulose. FEMS Microbiol Lett. 1994;1 16(3):293-9.

57. Ezeilo UR, Zakaria II, Huyop F, Wahab RA. Enzymatic breakdown of lignocellulosic biomass: the role of glycosyl hydrolases and lytic polysaccharide monooxygenases. Biotechnol Biotechnol Equip. 2017:31 (4):647-62.

58. Cantarel BL, Coutinho PM, Rancurel C, Bernard T, Lombard V, Henrissat B. The carbohydrate-active enzymes database (CAZy): an expert resource for glycogenomics. Nucleic Acids Res. 2009;37(Suppl_1):233-8.

59. Forsberg Z, Mackenzie AK, Sørlie M, Røhr ÅK, Helland R, Arvai AS, Vaaje-Kolstad G, Eijsink VG. Structural and functional characterization of a conserved pair of bacterial cellulose-oxidizing lytic polysaccharide monooxygenases. Proc Natl Acad Sci. 2014;1 11(23):8446-51.

60. Phillips CM, Beeson WT IV, Cate JH, Marletta MA. Cellobiose dehydrogenase and a copper-dependent polysaccharide monooxygenase potentiate cellulose degradation by Neurospora crassa. ACS Chem Biol. 2011:6(12):1399-406.

61. Levasseur A, Drula E, Lombard V, Coutinho PM, Henrissat B. Expansion of the enzymatic repertoire of the CAZy database to integrate auxiliary redox enzymes. Biotechnol Biofuels. 2013;6(1):41.

62. Hemsworth GR, Henrissat B, Davies GJ, Walton PH. Discovery and characterization of a new family of lytic polysaccharide monooxygenases. Nat Chem Biol. 2014;10(2):122.

63. Leggio LL, Simmons TJ, Poulsen JCN, Frandsen KE, Hemsworth GR, Stringer MA, Von Freiesleben P, Tovborg M, Johansen KS, De Maria L. Structure and boosting activity of a starch-degrading lytic polysaccharide monooxygenase. Nat Commun. 2015;6(1):1-9.

64. Walton PH, Davies GJ. On the catalytic mechanisms of lytic polysaccharide monooxygenases. Curr Opin Chem Biol. 2016;31:195-207.

65. Agger JW, Isaksen T, Várnai A, Vidal-Melgosa S, Willats WG, Ludwig R, Horn SJ, Eijsink VG, Westereng B. Discovery of LPMO activity on hemicelluloses shows the importance of oxidative processes in plant cell wall degradation. Proc Natl Acad Sci. 2014;111 (17):6287-92.

66. Fanuel M, Garajova S, Ropartz D, McGregor N, Brumer H, Rogniaux H, Berrin J-G. The Podospora anserina lytic polysaccharide monooxygenase Pa LPMO9H catalyzes oxidative cleavage of diverse plant cell wall matrix glycans. Biotechnol Biofuels. 2017;10(1):63.

67. Frommhagen M, Koetsier MJ, Westphal AH, Visser J, Hinz SW, Vincken J-P, Van Berkel WJ, Kabel MA, Gruppen H. Lytic polysaccharide monooxygenases from Myceliophthora thermophila C1 differ in substrate preference and reducing agent specificity. Biotechnol Biofuels. 2016;9(1):186.

68. Jagadeeswaran G, Gainey L, Prade R, Mort AJ. A family of AA9 lytic polysaccharide monooxygenases in Aspergillus nidulans is differentially regulated by multiple substrates and at least one is active on cellulose and xyloglucan. Appl Microbiol Biotechnol. 2016;100(10):4535-47.

69. Sorek N, Yeats TH, Szemenyei H, Youngs H, Somerville CR. The implications of lignocellulosic biomass chemical composition for the production of advanced biofuels. Bioscience. 2014. https://doi.org/10.1093/ biosci/bit1037.

70. Scharf ME. Termites as targets and models for biotechnology. Annu Rev Entomol. 2015;60:77-102.

71. Yang B, Wyman CE. Pretreatment: the key to unlocking low-cost celIulosic ethanol. Biofuels Bioproducts Biorefining. 2008;2(1):26-40.

72. de Gonzalo G, Colpa DI, Habib MHM, Fraaije MW. Bacterial enzymes involved in lignin degradation. J Biotechnol. 2016;236:110-9.

73. Sindhu R, Binod P, Pandey A. Biological pretreatment of lignocellulosic biomass-an overview. Biores Technol. 2016;199:76-82. 
74. Davidi L, Moraïs S, Artzi L, Knop D, Hadar Y, Arfi Y, Bayer EA. Toward combined delignification and saccharification of wheat straw by a laccasecontaining designer cellulosome. Syst Biol Appl. 2016;113(39):10854-9.

75. Salwan R, Sharma V. The role of actinobacteria in the production of industrial enzymes. New and future developments in microbial biotechnology and bioengineering. Elsevier; 2018. pp. 165-177.

76. Bode W, Huber R. Natural protein proteinase inhibitors and their interaction with proteinases. EJB Rev. Springer; 1993. pp.43-61.

77. Passari AK, Mishra VK, Singh G, Singh P, Kumar B, Gupta VK, Sarma RK, Saikia R, Singh BP. Insights into the functionality of endophytic actinobacteria with a focus on their biosynthetic potential and secondary metabolites production. Sci Rep. 2017;7(1):1-17.

78. Miyashita K, Fujii T, Sawada Y. Molecular cloning and characterization of chitinase genes from Streptomyces lividans 66. Microbiology. 1991;137(9):2065-72.

79. Techapun C, Poosaran N, Watanabe M, Sasaki K. Thermostable and alkaline-tolerant microbial cellulase-free xylanases produced from agricultural wastes and the properties required for use in pulp bleaching bioprocesses: a review. Process Biochem. 2003;38(9):1327-40.

80. Majumdar S, LukkT, Solbiati JO, Bauer S, Nair SK, Cronan JE, Gerlt JA. Roles of small laccases from Streptomyces in lignin degradation. Biochemistry. 2014;53(24):4047-58.

81. Doori M, Hunter I. Theoretical and practical studies on the metabolic engineering of streptomyces for production of butanols. J Microbiol Exp. 2017;5(7):00177.

82. Dixit V, Pant A. Comparative characterization of two serine endopeptidases from Nocardiopsis sp NCIM 5124. Biochimica et Biophysica Acta (BBA) General Subjects. 2000;1523(23):261-8.

83. Scott JJ, Oh D-C, Yuceer MC, Klepzig KD, Clardy J, Currie CR. Bacterial protection of beetle-fungus mutualism. Science. 2008;322(5898):63-63.

84. Watanabe Y, Shinzato N, Fukatsu T. Isolation of actinomycetes from termites' guts. Biosci Biotechnol Biochem. 2003;67(8):1797-801.

85. Vasanthakumar A, Handelsman J, Schloss PD, Bauer LS, Raffa KF. Gut microbiota of an invasive subcortical beetle, Agrilus planipennis Fairmaire, across various life stages. Environ Entomol. 2008;37(5):1344-53.

86. Lewin GR, Carlos C, Chevrette MG, Horn HA, McDonald BR, Stankey RJ, Fox BG, Currie CR. Evolution and ecology of Actinobacteria and their bioenergy applications. Annu Rev Microbiol. 2016;70:235-54.

87. Mihajlovski K, Buntić A, Milić M, Rajilić-Stojanović M, DimitrijevićBranković S: From Agricultural Waste to Biofuel: Enzymatic Potential of a Bacterial Isolate Streptomyces fulvissimus CKS7 for Bioethanol Production. Waste and Biomass Valorization 2020. pp. 1-10.

88. Arneodo JD, Etcheverry C, Thebe T, Babalola OO, Godoy MC, Talia P. Molecular evidence that cellulolytic bacterial genus Cohnella is widespread among Neotropical Nasutitermitinae from NE Argentina. Rev Argent Microbiol. 2018;51(1):77-80.

89. Arora STJMN, Mishra P: Microbial cellulolytic enzymes: diversity and biotechnology with reference to lignocellulosic biomass degradation. 2020

90. Han Q, Liu N, Robinson H, Cao L, Qian C, Wang Q, Xie L, Ding H, Wang Q, Huang Y. Biochemical characterization and crystal structure of a GH10 xylanase from termite gut bacteria reveal a novel structural feature and significance of its bacterial Ig-like domain. Biotechnol Bioeng. 2013;110(12):3093-103.

91. Talia P, Arneodo J. Lignocellulose degradation by termites. Termites and sustainable management. Springer; 2018. pp. 101-117.

92. Abo BO, Gao M, Wang Y, Wu C, Ma H, Wang Q. Lignocellulosic biomass for bioethanol: an overview on pretreatment, hydrolysis and fermentation processes. Rev Environ Health. 2019;34(1):57-68.

93. Arora R, Sharma NK, Kumar S, Sani RK. Lignocellulosic ethanol: feedstocks and bioprocessing. Bioethanol production from food crops. Elsevier; 2019. pp. 165-185.

94. Brodeur G, Yau E, Badal K, Collier J, Ramachandran K, Ramakrishnan S. Chemical and physicochemical pretreatment of lignocellulosic biomass: a review. Enzyme Research. 2011.

95. Harmsen P, Huijgen W, Bermudez L, Bakker R: Literature review of physical and chemical pretreatment processes for lignocellulosic biomass. Wageningen UR-Food \& Biobased Research; 2010.
96. Lu X, Zhang Y, Yang J, Liang Y. Enzymatic hydrolysis of corn stover after pretreatment with dilute sulfuric acid. Chem Eng Technol Industrial Chem Plant Equipment Process Eng Biotechnol. 2007;30(7):938-44.

97. Tran TTA, Le TKP, Mai TP, Nguyen DQ. Bioethanol production from lignocellulosic biomass. alcohol fuels-current technologies and future prospect. IntechOpen; 2019.

98. Bhandari N, Macdonald DG, Bakhshi NN. Kinetic studies of corn stover saccharification using sulphuric acid. Biotechnol Bioeng. 1984;26(4):320-7.

99. Cara C, Ruiz E, Oliva JM, Sáez F, Castro E. Conversion of olive tree biomass into fermentable sugars by dilute acid pretreatment and enzymatic saccharification. Biores Technol. 2007;99(6):1869-76.

100. Silverstein RA, Chen Y, Sharma-Shivappa RR, Boyette MD, Osborne J. A comparison of chemical pretreatment methods for improving saccharification of cotton stalks. Biores Technol. 2007;98(16):3000-11.

101. Mosier N, Hendrickson R, Ho N, Sedlak M, Ladisch MR. Optimization of $\mathrm{pH}$ controlled liquid hot water pretreatment of corn stover. Biores Technol. 2005;96(18):1986-93.

102. Tsegaye B, Balomajumder C, Roy P. Alkali pretreatment of wheat straw followed by microbial hydrolysis for bioethanol production. Environ Technol. 2017;40(9):1203-11.

103. Balan V. Current challenges in commercially producing biofuels from lignocellulosic biomass. ISRN Biotechnology; 2014. Doi: https://doi. org/10.1155/2014/463074.

104. Karimi K. Lignocellulose-based bioproducts. Germany: Springer; 2015.

105. Taherzadeh MJ, Karimi K. Enzyme-based hydrolysis processes for ethanol from lignocellulosic materials: a review. BioResources. 2007;2(4):707-38.

106. Axelsson J. Separate hydrolysis and fermentation of pretreated spruce. 2011

107. Alfani F, Gallifuoco A, Saporosi A, Spera A, Cantarella M. Comparison of SHF and SSF processes for the bioconversion of steam-exploded wheat straw. J Ind Microbiol Biotechnol. 2000;25(4):184-92.

108. Zabed H, Sahu J, Boyce A, Faruq G. Fuel ethanol production from lignocellulosic biomass: an overview on feedstocks and technological approaches. Renew Sustain Energy Rev. 2016;66:751-74.

109. Althuri A, Chintagunta AD, Sherpa KC, Banerjee R. Simultaneous saccharification and fermentation of lignocellulosic biomass. Biorefining of Biomass to Biofuels. Springer; 2018; pp. 265-285.

110. Liu F, Monroe E, Davis RW. Engineering microbial consortia for bioconversion of multisubstrate biomass streams to biofuels. BiofuelsChallenges and opportunities. IntechOpen; 2018.

111. Levin DB, Verbeke TJ, Munir R, Islam R, Ramachandran U, Lal S, Schellenberg J, Sparling R. Omics approaches for designing biofuel producing cocultures for enhanced microbial conversion of lignocellulosic substrates. Direct microbial conversion of biomass to advanced biofuels. Elsevier; 2015; pp. 335-363.

112. Fan Z: Consolidated bioprocessing for ethanol production. Biorefineries. Elsevier; 2014; pp. 141-160.

113. Mbaneme-Smith V, Chinn MS. Consolidated bioprocessing for biofuel production: recent advances. Energy Emission Control Technol. 2015;3:23.

114. Schuster BG, Chinn MS. Consolidated bioprocessing of lignocellulosic feedstocks for ethanol fuel production. BioEnergy Res. 2013;6(2):416-35.

115. Kim S, Baek S-H, Lee K, Hahn J-S. Cellulosic ethanol production using a yeast consortium displaying a minicellulosome and $\beta$-glucosidase. Microb Cell Fact. 2013:12(1):14.

116. Azman S, Khadem AF, Van Lier JB, Zeeman G, Plugge CM. Presence and role of anaerobic hydrolytic microbes in conversion of lignocellulosic biomass for biogas production. Crit Rev Environ Sci Technol. 2015;45(23):2523-64.

117. Fockink DH, Maceno MAC, Ramos LP. Production of cellulosic ethanol from cotton processing residues after pretreatment with dilute sodium hydroxide and enzymatic hydrolysis. BioresourceTechnol. 2015;187:91-6.

118. Behera SS, Ray RC. Solid state fermentation for production of microbial cellulases: Recent advances and improvement strategies. Int J Biol Macromol. 2016;86:656-69. 
119. García-Aparicio M, Oliva J, Manzanares P, Ballesteros M, Ballesteros I, González A, Negro M. Second-generation ethanol production from steam exploded barley straw by Kluyveromyces marxianus CECT 10875. Fuel. 2011;90(4):1624-30.

120. Parisutham V, Kim TH, Lee SK. Feasibilities of consolidated bioprocessing microbes: from pretreatment to biofuel production. Biores Technol. 2014;161:431-40.

121. Kim J-H, Block DE, Mills DA. Simultaneous consumption of pentose and hexose sugars: an optimal microbial phenotype for efficient fermentation of lignocellulosic biomass. Appl Microbiol Biotechnol. 2010;88(5):1077-85.

122. Canilha L, Chandel AK. Bioconversion of sugarcane biomass into ethanol: an overview about composition, pretreatment methods, detoxification of hydrolysates, enzymatic saccharification, and ethanol fermentation. BioMed Res Int. 2012. https://doi.org/10.1155/2012/989572.

123. Martiniano SE, Chandel AK, Soares LC, Pagnocca FC, da Silva SS. Evaluation of novel xylose-fermenting yeast strains from Brazilian forests for hemicellulosic ethanol production from sugarcane bagasse. 3 Biotech. 2013;3(5):345-52.

124. Moysés DN, Reis VCB, Almeida JRMD, Moraes LMPD, Torres FAG. Xylose fermentation by Saccharomyces cerevisiae: challenges and prospects. Int J Mol Sci. 2016;17(3):207

125. Chandel AK, Singh OV, Chandrasekhar G, Rao LV, Narasu ML. Key drivers influencing the commercialization of ethanol-based biorefineries. J Commercial Biotechnol. 2010;16(3):239-57.

126. Senatham S, Chamduang T, Kaewchingduang $Y$, Thammasittirong A, Srisodsuk M, Elliston A, Roberts IN, Waldron KW. Thammasittirong SN-R: enhanced xylose fermentation and hydrolysate inhibitor tolerance of Scheffersomyces shehatae. SpringerPlus. 2016;5(1):1-8.

127. Li P, Fu X, Zhang L, Li S. CRISPR/Cas-based screening of a gene activation library in Saccharomyces cerevisiae identifies a crucial role of OLE1 in thermotolerance. Microb Biotechnol. 2019;12(6):1154.

128. McMillan JD, Beckham GT. Thinking big: towards ideal strains and processes for large-scale aerobic biofuels production. Microb Biotechnol. 2017:10(1):40-2.

129. Du J, Shao Z, Zhao H. Engineering microbial factories for synthesis of value-added products. J Ind Microbiol Biotechnol. 2011;38(8):873-90.

130. Chua P, Somanchi A. Genetically engineered microorganisms that metabolize xylose. In.: Google Patents; 2016.

131. Milne N, Wahl S, van Maris A, Pronk J, Daran J. Excessive by-product formation: a key contributor to low isobutanol yields of engineered Saccharomyces cerevisiae strains. Metabolic Eng Commun. 2016:3:39-51.

132. Romaní A, Pereira F, Johansson B, Domingues L. Metabolic engineering of Saccharomyces cerevisiae ethanol strains PE-2 and CAT-1 for efficient lignocellulosic fermentation. Biores Technol. 2015;179:150-8.

133. Pasotti L, Zucca S, Casanova M, Micoli G, De Angelis MGC, Magni P. Fermentation of lactose to ethanol in cheese whey permeate and concentrated permeate by engineered Escherichia coli. BMC Biotechnol. 2017;17(1):48

134. Mendez-Perez D, Alonso-Gutierrez J, Hu Q, Molinas M, Baidoo EE, Wang G, Chan LJ, Adams PD, Petzold CJ, Keasling JD. Production of jet fuel precursor monoterpenoids from engineered Escherichia coli. Biotechnol Bioeng. 2017:114:1703-12.

135. Jessop-Fabre MM, Jakočiūnas T, Stovicek V, Dai Z, Jensen MK, Keasling JD, Borodina I. EasyClone-MarkerFree: a vector toolkit for marker-less integration of genes into Saccharomyces cerevisiae via CRISPR-Cas9. Biotechnol J. 2016;11(8):1110-7.

136. Parisutham V, Sathesh-Prabu C, Mukhopadhyay A, Lee SK, Keasling JD. Intracellular cellobiose metabolism and its applications in lignocellulose-based biorefineries. Bioresource Technol. 2017;239:496-506.

137. Sievert C, Nieves LM, Panyon LA, Loeffler T, Morris C, Cartwright $R A$, Wang $X$. Experimental evolution reveals an effective avenue to release catabolite repression via mutations in XyIR. Proc Natl Acad Sci. 2017;114(28):7349-54

138. Flores AD, Ayla EZ, Nielsen DR, Wang X. Engineering a synthetic, catabolically orthogonal coculture system for enhanced conversion of lignocellulose-derived sugars to ethanol. ACS Synthetic Biol. 2019:8(5):1089-99.

139. Bilal M, lqbal HM, Hu H, Wang W, Zhang X. Metabolic engineering and enzyme-mediated processing: a biotechnological venture towards biofuel production-a review. Renew Sustain Energy Rev. 2018;82:436-47.
140. Ling H, Teo W, Chen B, Leong SSJ, Chang MW. Microbial tolerance engineering toward biochemical production: from lignocellulose to products. Curr Opin Biotechnol. 2014;29:99-106.

141. Mukhopadhyay A. Tolerance engineering in bacteria for the production of advanced biofuels and chemicals. Trends Microbiol. 2015;23(8):498-508.

142. Kim SR, Skerker JM, Kang W, Lesmana A, Wei N, Arkin AP, Jin Y-S. Rational and evolutionary engineering approaches uncover a small set of genetic changes efficient for rapid xylose fermentation in Saccharomyces cerevisiae. PLOS ONE. 2013;8(2):e57048.

143. Alper H, Moxley J, Nevoigt E, Fink GR, Stephanopoulos G. Engineering yeast transcription machinery for improved ethanol tolerance and production. Science. 2006;314(5805):1565-8.

144. Atsumi S, Hanai T, Liao JC. Non-fermentative pathways for synthesis of branched-chain higher alcohols as biofuels. Nature. 2008:451(7174):86-9.

145. El-Rotail AA, Zhang L, Li Y, Liu SP, Shi GY. A novel constructed SPT15 mutagenesis library of Saccharomyces cerevisiae by using gTME technique for enhanced ethanol production. AMB Express. 2017;7(1):111.

146. Xu P: Production of chemicals using dynamic control of metabolic fluxes. 2017.

147. Hollinshead W, He L, Tang YJ. Biofuel production: an odyssey from metabolic engineering to fermentation scale-up. Front Microbiol. 2014. https://doi.org/10.3389/fmicb.2014.00344.

148. Majidian P, Tabatabaei M, Zeinolabedini M, Naghshbandi MP, Chisti Y. Metabolic engineering of microorganisms for biofuel production. Renew Sustain Energy Rev. 2017;82:3863-85.

149. Bashor CJ, Horwitz AA, Peisajovich SG, Lim WA. Rewiring cells: synthetic biology as a tool to interrogate the organizational principles of living systems. Ann Rev Biophysics. 2010;39:515-37.

150. Seshasayee AS, Fraser GM, Babu MM, Luscombe NM. Principles of transcriptional regulation and evolution of the metabolic system in $E$. coli. Genome Res. 2009;19(1):79-91.

151. Lv Y, Qian S, Du G, Chen J, Zhou J, Xu P. Coupling feedback genetic circuits with growth phenotype for dynamic population control and intelligent bioproduction. UMBC Faculty Collection. 2019.

152. Xu P, Li L, Zhang F, Stephanopoulos G, Koffas M. Improving fatty acids production by engineering dynamic pathway regulation and metabolic control. Proc Natl Acad Sci. 2014;111(31):11299-304.

153. Nielsen J. It is all about metabolic fluxes. J Bacteriol. 2003;185(24):7031-5.

154. Lynd LR, Weimer PJ, Van ZyI WH, Pretorius IS. Microbial cellulose utilization: fundamentals and biotechnology. Microbiol Mol Biol Rev. 2002;66(3):506-77.

155. Avanthi A, Banerjee R. A strategic laccase mediated lignin degradation of lignocellulosic feedstocks for ethanol production. Ind Crops Prod. 2016;92:174-85.

156. Menon V, Rao M. Trends in bioconversion of lignocellulose: biofuels, platform chemicals \& biorefinery concept. Prog Energy Combust Sci. 2012;38(4):522-50.

157. Lynd LR, Laser MS, Bransby D, Dale BE, Davison B, Hamilton R, Himme M, Keller M, McMillan JD, Sheehan J, et al. How biotech can transform biofuels. Nat Biotechnol. 2008:26:169-72.

158. Adrio JL, Demain AL. Microbial enzymes: tools for biotechnological processes. In. 2014;4:117-39.

159. Ravindran R, Jaiswal A. Microbial enzyme production using lignocellulosic food industry wastes as feedstock: a review. Bioengineering. 2016:3(4):30

160. Warnecke F, Luginbühl P, Ivanova N, Ghassemian M, Richardson TH, Stege JT, Cayouette M, McHardy AC, Djordjevic G, Aboushadi N, et al. Metagenomic and functional analysis of hindgut microbiota of a woodfeeding higher termite. Nature. 2007;450(7169):560-5.

161. Batista-García RA, del Rayo S-C, Talia P, Jackson SA, O'Leary ND, Dobson $A D$, Folch-Mallol JL. From lignocellulosic metagenomes to lignocellulolytic genes: trends, challenges and future prospects. Biofuels Bioprod Biorefin. 2016;10(6):864-82.

162. Bibra M, Wang J, Squillace P, Pinkelman R, Papendick S, Schneiderman S, Wood V, Amar V, Kumar S, Salem D: Biofuels and value-added products from extremophiles. . In book: advances in biotechnology, Chapter: 2. Publisher: I.K. International Publishing House New Delhi; 2015. p. 17-51. 
163. Pandey S. Cellulases in conversion of lignocellulosic waste into secondgeneration biofuel. Int J Adv Res. 2015;3(7):392-9.

164. Saini JK, Saini R, Tewari L. Lignocellulosic agriculture wastes as biomass feedstocks for second-generation bioethanol production: concepts and recent developments. 3 Biotech. 2015;5(4):337-53.

165. Avanthi A, Kumar S, Sherpa KC, Banerjee R. Bioconversion of hemicelluloses of lignocellulosic biomass to ethanol: an attempt to utilize pentose sugars. Biofuels. 2016; pp. 1-14.

166. Kang A, Lee TS. Converting sugars to biofuels: ethanol and beyond. Bioengineering. 2015;2(4):184-203.

167. Phelan RM, Sekurova ON, Keasling JD, Zotchev SB. Engineering terpene biosynthesis in Streptomyces for production of the advanced biofuel precursor bisabolene. ACS Synthetic Biol. 2014:4(4):393-9.

168. Jullesson D, David F, Pfleger B, Nielsen J. Impact of synthetic biology and metabolic engineering on industrial production of fine chemicals. Biotechnol Adv. 2015;33(7):1395-402.

169. Kern A, Tilley E, Hunter IS, Legiša M, Glieder A. Engineering primary metabolic pathways of industrial micro-organisms. J Biotechnol. 2007;129(1):6-29.

170. Singh V, Mani I, Chaudhary DK, Dhar PK. Metabolic engineering of biosynthetic pathway for production of renewable biofuels. Appl Biochem Biotechnol. 2014;172(3):1158-71.

171. Papoutsakis ET. Reassessing the progress in the production of advanced biofuels in the current competitive environment and beyond: what are the successes and where progress eludes us and why. Ind Eng Chem Res. 2015;54(42):10170-82

172. Rabinovitch-Deere CA, Oliver JW, Rodriguez GM, Atsumi S. Synthetic biology and metabolic engineering approaches to produce biofuels. Chem Rev. 2013;113(7):4611-32.

173. Cho C, Choi SY, Luo ZW, Lee SY. Recent advances in microbial production of fuels and chemicals using tools and strategies of systems metabolic engineering. Biotechnol Adv. 2015;33(7):1455-66.

174. Zhao X, Xiong L, Zhang M, Bai F. Towards efficient bioethanol production from agricultural and forestry residues: exploration of unique natural microorganisms in combination with advanced strain engineering. BioresourceTechnol. 2016;215:84-91.

175. Chen Y, Nielsen J. Biobased organic acids production by metabolically engineered microorganisms. Curr Opin Biotechnol. 2016;37:165-72.

176. Park Y-C, Oh EJ, Jo J-H, Jin Y-S, Seo J-H. Recent advances in biological production of sugar alcohols. Curr Opin Biotechnol. 2016;37:105-13.

177. Dornau A, Robson JF, Thomas GH, McQueen-Mason SJ. Robust microorganisms for biofuel and chemical production from municipal solid waste. Microb Cell Fact. 2020;19(1):1-18.

178. Boock JT, Freedman AJ, Tompsett GA, Muse SK, Allen AJ, Jackson LA, Castro-Dominguez B, Timko MT, Prather KL, Thompson JR. Engineered microbial biofuel production and recovery under supercritical carbon dioxide. Nat Commun. 2019;10(1):1-12.

179. De Bhowmick G, Koduru L, Sen R. Metabolic pathway engineering towards enhancing microalgal lipid biosynthesis for biofuel application - a review. Renew Sustain Energy Rev. 2015;50:1239-53.

180. Ullah MW, Khattak WA, UI-Islam M, Khan S, Park JK. Metabolic engineering of synthetic cell-free systems: strategies and applications. Biochem Eng J. 2016:105:391-405.

181. Runguphan W, Keasling JD. Metabolic engineering of Saccharomyces cerevisiae for production of fatty acid-derived biofuels and chemicals. Metab Eng. 2014;21:103-13.

182. Way Jeffrey C, Collins James J, Keasling Jay D, Silver Pamela A. Integrating biological redesign: where synthetic biology came from and where it needs to go. Cell. 2014;157(1):151-61.

183. Liao JC, Mi L, Pontrelli S, Luo S. Fuelling the future: microbial engineering for the production of sustainable biofuels. Nat Rev Microbiol. 2016;14(5):288-304

184. Lo J, Olson DG, Murphy SJL, Tian L, Hon S, Lanahan A, Guss AM, Lynd LR. Engineering electron metabolism to increase ethanol production in Clostridium thermocellum. Metab Eng. 2017;39:71-9.

185. Chen Z, Huang J, Wu Y, Wu W, Zhang Y, Liu D. Metabolic engineering of Corynebacterium glutamicum for the production of 3-hydroxypropionic acid from glucose and xylose. Metab Eng. 2017;39:151-8.

186. Liew F, Henstra AM, Köpke M, Winzer K, Simpson SD, Minton NP. Metabolic engineering of Clostridium autoethanogenum for selective alcohol production. Metab Eng. 2017;40:104-14.
187. Varman AM, Xiao Y, Pakrasi HB, Tang YJ. Metabolic Engineering of Synechocystis sp. Strain PCC 6803 for Isobutanol Production. Appl Environ Microbiol. 2013;79(3):908-14.

188. Hirokawa Y, Maki Y, Hanai T. Improvement of 1,3-propanediol production using an engineered cyanobacterium, Synechococcus elongatus by optimization of the gene expression level of a synthetic metabolic pathway and production conditions. Metab Eng. 2017;39:192-9.

189. Liu R, Zhu F, Lu L, Fu A, Lu J, Deng Z, Liu T. Metabolic engineering of fatty acyl-ACP reductase-dependent pathway to improve fatty alcohol production in Escherichia coli. Metab Eng. 2014;22:10-21.

190. Lian J, Chao R, Zhao H. Metabolic engineering of a Saccharomyces cerevisiae strain capable of simultaneously utilizing glucose and galactose to produce enantiopure (2R,3R)-butanediol. Metab Eng. 2014:23:92-9.

191. Chen Z, Wu Y, Huang J, Liu D. Metabolic engineering of Klebsiella pneumoniae for the de novo production of 2-butanol as a potential biofuel. Biores Technol. 2015;197:260-5.

192. Li L, Li K, Wang Y, Chen C, Xu Y, Zhang L, Han B, Gao C, Tao F, Ma C. Metabolic engineering of Enterobacter cloacae for high-yield production of enantiopure (2R, 3R)-2, 3-butanediol from lignocellulose-derived sugars. Metab Eng. 2015;28:19-27.

193. Hu B, Lidstrom ME. Metabolic engineering of Methylobacterium extorquens AM1 for 1-butanol production. Biotechnol Biofuels. 2014;7(1):156

194. Yang X, Xu M, Yang S-T. Metabolic and process engineering of Clostridium cellulovorans for biofuel production from cellulose. Metab Eng. 2015;32:39-48.

195. Cha M, Chung D, Elkins JG, Guss AM, Westpheling J. Metabolic engineering of Caldicellulosiruptor bescii yields increased hydrogen production from lignocellulosic biomass. Biotechnol Biofuels. 2013;6(1):85.

196. Avalos JL, Fink GR, Stephanopoulos G. Compartmentalization of metabolic pathways in yeast mitochondria improves the production of branched-chain alcohols. Nat Biotechnol. 2013;31(4):335.

197. Schadeweg V, Boles E. Increasing n-butanol production with Saccharomyces cerevisiae by optimizing acetyl-CoA synthesis, NADH levels and trans-2-enoyl-CoA reductase expression. Biotechnol Biofuels. 2016;9(1):257.

198. Ko JK, Enkh-Amgalan T, Gong G, Um Y, Lee SM. Improved bioconversion of lignocellulosic biomass by Saccharomyces cerevisiae engineered for tolerance to acetic acid. GCB Bioenergy. 2020;12(1):90-100.

199. Yu L, Xu M, Tang IC, Yang ST. Metabolic engineering of Clostridium tyrobutyricum for n-butanol production through co-utilization of glucose and xylose. Biotechnol Bioeng. 2015;112(10):2134-41.

200. Luo H, Zeng Q, Han S, Wang Z, Dong Q, Bi Y, Zhao Y. High-efficient n-butanol production by co-culturing Clostridium acetobutylicum and Saccharomyces cerevisiae integrated with butyrate fermentative supernatant addition. World J Microbiol Biotechnol. 2017;33(4):76.

201. Das M, Patra P, Ghosh A. Metabolic engineering for enhancing microbial biosynthesis of advanced biofuels. Renew Sustain Energy Rev. 2020:119:109562.

202. Argyros DA, Tripathi SA, Barrett TF, Rogers SR, Feinberg LF, Olson DG, Foden JM, Miller BB, Lynd LR, Hogsett DA. High ethanol titers from cellulose by using metabolically engineered thermophilic, anaerobic microbes. Appl Environ Microbiol. 2011:77(23):8288-94.

203. Zhang M, Eddy C, Deanda K, Finkelstein M, Picataggio S. Metabolic engineering of a pentose metabolism pathway in ethanologenic Zymomonas mobilis. Science. 1995;267(5195):240-3.

204. Majidian P, Tabatabaei M, Zeinolabedini M, Naghshbandi MP, Chisti Y. Metabolic engineering of microorganisms for biofuel production. Renew Sustain Energy Rev. 2018:82:3863-85.

205. Wang $\mathrm{H}, \mathrm{Cao} \mathrm{S}$, Wang WT, Wang KT, Jia X. Very high gravity ethanol and fatty acid production of Zymomonas mobilis without amino acid and vitamin. J Ind Microbiol Biotechnol. 2016;43(6):861-71.

206. Romero S, Merino E, Bolívar F, Gosset G, Martinez A. Metabolic engineering of Bacillus subtilis for ethanol production: lactate dehydrogenase plays a key role in fermentative metabolism. Appl Environ Microbiol. 2007:73(16):5190-8.

207. Tamaru Y, Miyake H, Kuroda K, Nakanishi A, Matsushima C, Doi RH, Ueda M. Comparison of the mesophilic cellulosome-producing Clostridium cellulovorans genome with other cellulosome-related clostridial genomes. Microb Biotechnol. 2011;4(1):64-73. 
208. Bao T, Zhao J, Li J, Liu X, Yang S-T. n-Butanol and ethanol production from cellulose by Clostridium cellulovorans overexpressing heterologous aldehyde/alcohol dehydrogenases. Biores Technol. 2019;285:121316.

209. Hoang PTN, Ko JK, Gong G, Um Y, Lee S-M. Genomic and phenotypic characterization of a refactored xylose-utilizing Saccharomyces cerevisiae strain for lignocellulosic biofuel production. Biotechnol Biofuels. 2018;11(1):268.

210. Long MR, Ong WK, Reed JL. Computational methods in metabolic engineering for strain design. Curr Opin Biotechnol. 2015;34:135-41.

211. Shabestary K, Hudson EP. Computational metabolic engineering strategies for growth-coupled biofuel production by Synechocystis. Metabolic Eng Commun. 2016;3:216-26.

212. Roointan A, Morowvat MH. Road to the future of systems biotechnology: CRISPR-Cas-mediated metabolic engineering for recombinant protein production. Biotechnol Genet Eng Rev. 2016;32(1-2):74-91.

213. Rollin JA, del Campo JM, Myung S, Sun F, You C, Bakovic A, Castro R, Chandrayan SK, Wu C-H, Adams MW. High-yield hydrogen production from biomass by in vitro metabolic engineering: mixed sugars coutilization and kinetic modeling. Proc Natl Acad Sci. 2015;112(16):4964-9.

214. Jojima T, Noburyu R, Sasaki M, Tajima T, Suda M, Yukawa H, Inui M. Metabolic engineering for improved production of ethanol by Corynebacterium glutamicum. Appl Microbiol Biotechnol. 2015;99(3):1165-72.

215. Cho S, Shin J, Cho B-K. Applications of CRISPR/Cas system to bacterial metabolic engineering. Int J Mol Sci. 2018;19(4):1089.

216. Agati G, Foschi L, Grossi N, Guglielminetti L, Cerovic ZG. Fluorescencebased versus reflectance proximal sensing of nitrogen content in Paspalum vaginatum and Zoysia matrella turfgrasses. Eur J Agronomy. 2013;45:39-51.

217. Zhang S, Guo F, Yan W, Dai Z, Zhou J, Dong W, Jiang M, Zhang W, Xin F. Recent advances of CRISPR-Cas9-based genetic engineering in industrial biology. Front Bioeng Biotechnol. 2019;7:459.

218. Jinek M, Chylinski K, Fonfara I, Hauer M, Doudna JA, Charpentier E. A programmable dual-RNA-guided DNA endonuclease in adaptive bacterial immunity. Science. 2012;337(6096):816-21.

219. Deltcheva E, Chylinski K, Sharma CM, Gonzales K, Chao Y, Pirzada ZA, Eckert MR, Vogel J, Charpentier E. CRISPR RNA maturation by trans-encoded small RNA and host factor RNase III. Nature. 2011;471(7340):602-7.

220. Luo ML, Mullis AS, Leenay RT, Beisel CL. Repurposing endogenous type I CRISPR-Cas systems for programmable gene repression. Nucleic Acids Res. 2015;43(1):674-81.

221. Senturk S, Shirole NH, Nowak DG, Corbo V, Pal D, Vaughan A, Tuveson DA, Trotman LC, Kinney JB, Sordella R. Rapid and tunable method to temporally control gene editing based on conditional Cas9 stabilization. Nat Commun. 2017;8(1):1-10.

222. Qi LS, Larson MH, Gilbert LA, Doudna JA, Weissman JS, Arkin AP, Lim WA Repurposing CRISPR as an RNA-guided platform for sequence-specific control of gene expression. Cell. 2013;152(5):1173-83.

223. Carroll D. Genome engineering with zinc-finger nucleases. Genetics. 2011:188(4):773-82

224. Fokum E, Zabed HM, Guo Q, Yun J, Yang M, Pang H, An Y, Li W, Qi X. Metabolic engineering of bacterial strains using CRISPR/Cas9 systems for biosynthesis of value-added products. Food Biosci. 2019;28:125-32.

225. Moreno AM, Mali P. Therapeutic genome engineering via CRISPR-Cas systems. Wiley Interdisciplinary Rev Syst Biol Med. 2017;9(4):e1380.

226. d'Espaux L, Ghosh A, Runguphan W, Wehrs M, Xu F, Konzock O, Dev I, Nhan M, Gin J, Apel AR. Engineering high-level production of fatty alcohols by Saccharomyces cerevisiae from lignocellulosic feedstocks. Metab Eng. 2017:42:115-25.

227. Abdelaal AS, Jawed K, Yazdani SS. CRISPR/Cas9-mediated engineering of Escherichia coli for n-butanol production from xylose in defined medium. J Ind Microbiol Biotechnol. 2019;46(7):965-75.

228. Wang S, Dong S, Wang P, Tao Y, Wang Y. Genome editing in Clostridium saccharoperbutylacetonicum N1-4 with the CRISPR-Cas9 system. Appl Environ Microbiol. 2017:83(10):e00233.

229. Wasels F, Jean-Marie J, Collas F, López-Contreras AM, Ferreira NL. A twoplasmid inducible CRISPR/Cas9 genome editing tool for Clostridium acetobutylicum. J Microbiol Methods. 2017;140:5-11.

230. Wang Y, Chen L, Zhang W. Proteomic and metabolomic analyses reveal metabolic responses to 3-hydroxypropionic acid synthesized internally in cyanobacterium Synechocystis sp. PCC 6803. Biotechnol Biofuels. 2016;9(1):209.

231. Alonso-Gutierrez J, Kim E-M, Batth TS, Cho N, Hu Q, Chan LJG, Petzold CJ, Hillson NJ, Adams PD, Keasling JD. Principal component analysis of proteomics (PCAP) as a tool to direct metabolic engineering. Metab Eng. 2015;28:123-33.

232. Bhandiwad A, Shaw AJ, Guss A, Guseva A, Bahl H, Lynd LR. Metabolic engineering of Thermoanaerobacterium saccharolyticum for n-butanol production. Metab Eng. 2014;21:17-25.

\section{Publisher's Note}

Springer Nature remains neutral with regard to jurisdictional claims in published maps and institutional affiliations.
Ready to submit your research? Choose BMC and benefit from:

- fast, convenient online submission

- thorough peer review by experienced researchers in your field

- rapid publication on acceptance

- support for research data, including large and complex data types

- gold Open Access which fosters wider collaboration and increased citations

- maximum visibility for your research: over $100 \mathrm{M}$ website views per year

At BMC, research is always in progress.

Learn more biomedcentral.com/submissions 